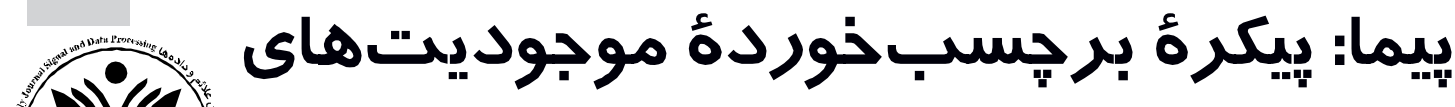

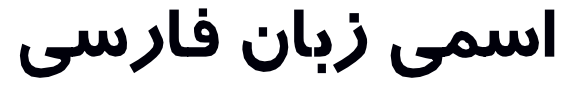

مهرساسادات شهشهمانى، مهيدى محسنى، آزاده شاكرى *و هشام فيلى

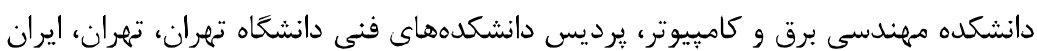

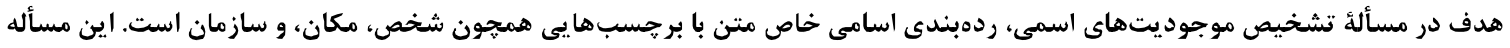

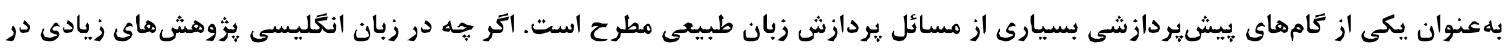

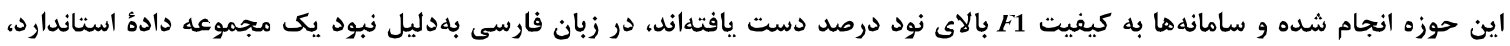

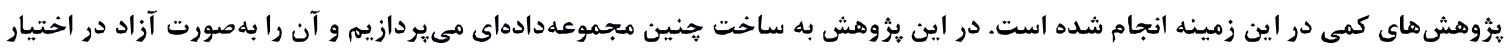

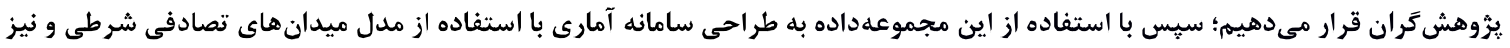

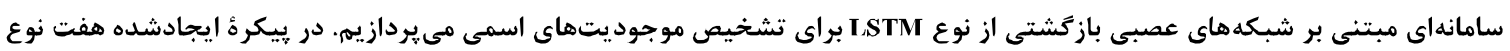

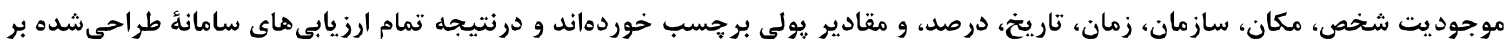

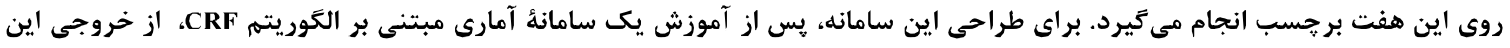

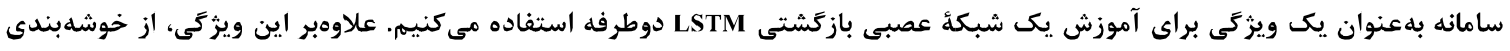

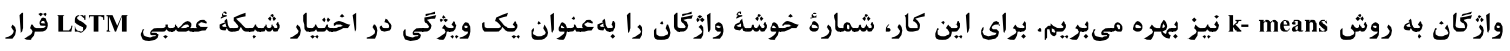

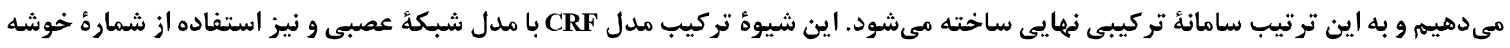

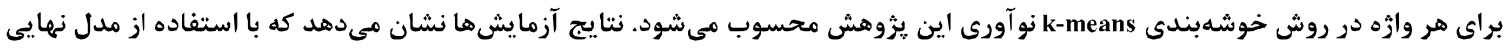

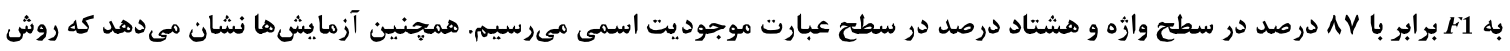

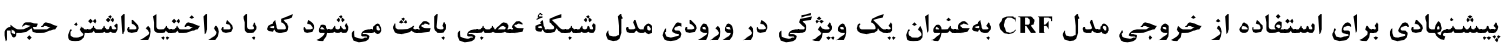

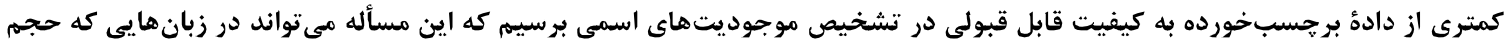

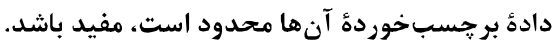
وازَّان كليدى: بيكرةٔ موجوديتهاى اسمى، تشخيص موجوديتهاى اسمى، روش قاعدهمحور، روش مبتنى بر يادكيرى عميق، روش

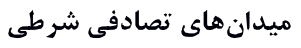

\section{PAYMA: A Tagged Corpus of Persian Named Entities}

\section{Mahsa Sadat Shahshahani, Mahdi Mohseni, Azadeh Shakery* \& Heshaam Faili}

Department of Electrical and Computer Engineering, College of Engincering, University of

Tehran, Tehran, Iran

\begin{abstract}
The goal in the named entity recognition task is to classify proper nouns of a piece of text into classes such as person, location, and organization. Named entity recognition is an important preprocessing step in many natural language processing tasks such as question-answering and summarization. Although many research studies have been conducted in this area in English and the state-of-the-art NER systems have reached performances of higher than 90 percent in terms of F1 measure, there are very few research studies on this
\end{abstract}

* Corresponding author * نويسنده عهلهدار مكاتبات 
task in Persian. One of the main important reasons for this may be the lack of a standard Persian NER dataset to train and test the NER systems. In this research we create a standard tagged Persian NER dataset which will be distributed freely for research purposes. In order to construct this standard dataset, we studied the existing standard NER datasets in English and came to the conclusion that almost all of these datasets are constructed using news data. Thus we collected documents from ten news websites in Persian. In the next step, in order to provide the annotators with guidelines to tag these documents, we studied the guidelines used for constructing CoNLL and MUC English datasets and created our own guidelines considering the Persian linguistic rules. Using these guidelines, all words in documents can be labeled as person, location, organization, time, date, percent, currency, or other (words that are not in any of these 7 classes). We use IOB encoding for annotating named entities in documents, like most of the existing English NER datasets. Using this encoding, the first token of a named entity is labeled with $B$, and the next tokens (if exist) are labeled with I. The words that are not part of any named entity are labeled with $O$. The constructed corpus, named PAYMA, consists of 709 documents and includes 302530 tokens. 41148 tokens out of these tokens are labeled as named entities and the others are labeled as $O$. In order to determine the inter-annotator agreement, 160 documents were labeled by a second annotator. Kappa statistic was estimated as $95 \%$ using words that are labeled as named entities. After creating the dataset, we used the dataset to design a hybrid system for named entity recognition. We trained a statistical system based on the CRF algorithm, and used its output as a feature to train a bidirectional LSTM recurrent neural network. Moreover, we used the k-means word clustering method to cluster the words and fed the cluster number of each word to the LSTM neural network. This form of combining CRF with neural networks and using the cluster number for each word is the novelty of this research work. Experimental results show that the final model can reach an $F 1$ score of $87 \%$ at word-level and $80 \%$ at phrase level.

Keywords: Persian named entity corpus, named entity recognition, rule-based model, deep-learning based model, conditional random field's method

$$
\begin{aligned}
& \text { استفاده از بخشى از ي ييكرة بىجنخان ساخته شده است و }
\end{aligned}
$$

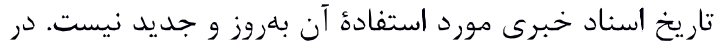

$$
\begin{aligned}
& \text { اين يزوهش به ساخت يك مجموعه داده استاندارد با حجم بهم }
\end{aligned}
$$

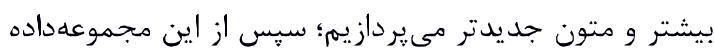

$$
\begin{aligned}
& \text { براى آموزش و ارزيابى سامانهاى جهت شناسايى و ردهبندى } \\
& \text { موجوديتهاى اسمى در متون فارسى استفاده مى كنيم. }
\end{aligned}
$$

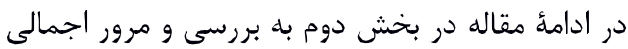

$$
\begin{aligned}
& \text { سامانه هاى تشخيص موجوديت اسمى موجود براى زبانهاى }
\end{aligned}
$$

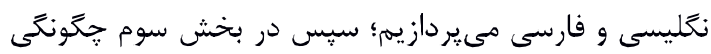

$$
\begin{aligned}
& \text { ساخت مجموعه داده استاندارد موجوديتهاى اسمى را بهطور } \\
& \text { مشروح توضيح مى مهيم. در بخش جهارم به شرح ساهانئ }
\end{aligned}
$$

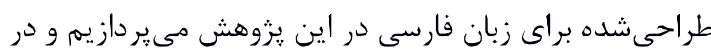

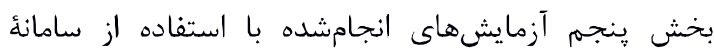

$$
\begin{aligned}
& \text { طراحىشده و مجموعه داده فراهمشده را شرح مى دهيم و ونهم }
\end{aligned}
$$

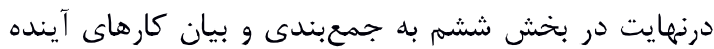

$$
\begin{aligned}
& \text { مىيردازيم. }
\end{aligned}
$$

$$
\text { r- كارهاى بيشين }
$$

با توجه به آن كه تلاش مى كنيهم مجموعهدادة استانداردى

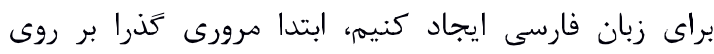

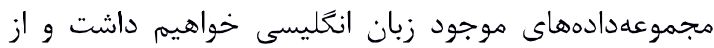
آنجا كه مىخواهيم با بررسى كارهاى يِيشين انجامشده در

\footnotetext{
${ }^{1}$ named entitics
}

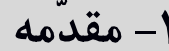

موجوديتهاى اسمى' ، واحدهاى اسمى معنادار متن هستند

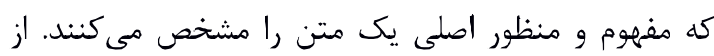

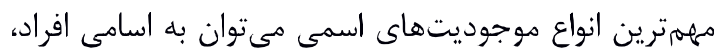

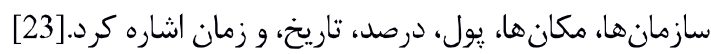

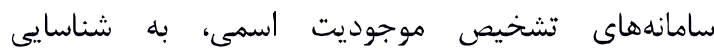

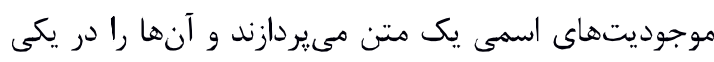

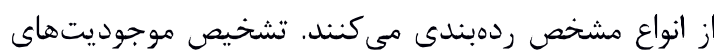

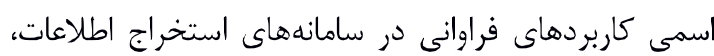

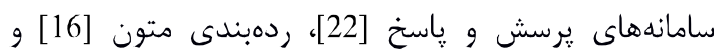
بهينهسازى جستجو [24] دارد.

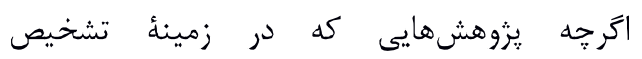

موجوديتهاى اسمى انجامشده در زبانهاى مختلف وسيع بوده و تاحدودى نتايج قابل قبولى حاصل شده است، فعاليتهاى انجامشده در اين زمينه در زبان فارسى جندان گسترده نبوده و نتايج ارايهشده ياسخَّى نيازها نيست. در

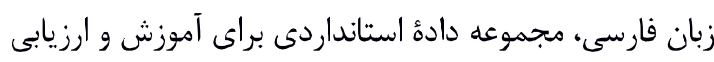
سامانهاى تشخيص موجوديت اسمى وجود ندارد كه همين مسأله انجام يثوهش در اين زمينه را بسيار دشوار كرده است. تنها مجموعه داده موجود براى زبان فارسى در [26] ارائه شده زئه است كه برجسبهاى آن شامل شخص، مكان، سازمان، امكانات، رويداد، و ساير موجوديتهاست. اين مجموعه داده با 


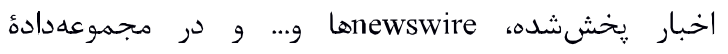
ACE2004 از متون اخبار يخششدة راديويى استفاده شده

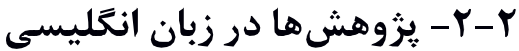

r-r

مسأله تشخيص موجوديتهاى اسمى ذاتاً از جنس مسائل

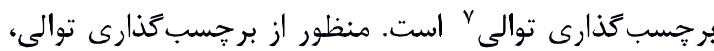
دراختيارداشتن دنبالهاى از اشياست كه با توجه به ترتيب آني آنها قرار است به تكتى اشيا برجسبى تعلق كيرد. در مسألهأ

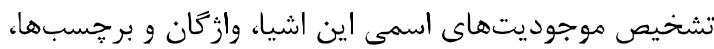
انواع موجوديتهاى اسمى هستند. به همين دليل از ابتداى

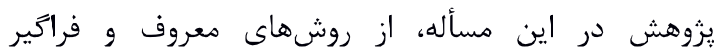

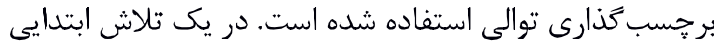

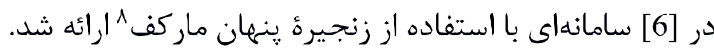

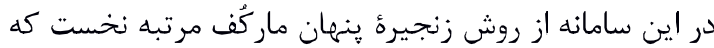

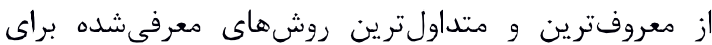
برجسب كذارى دنبالههاست، استفاده شده است. در مر مدل زنجيرهٔ هنههان ماركف، حند متغير مشاهدهشده وجود دارد كه با توجه به آنها و با دانستن احتمال انتقال بين حالتها

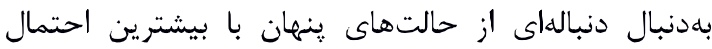

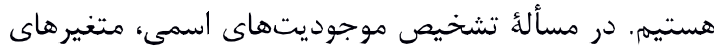
مشاهدهشده، وازٔكان و حالتهاى ينهان برجسب هُها هستند.

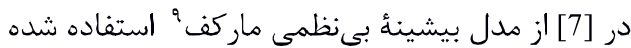

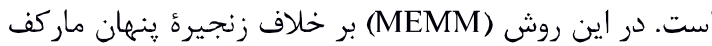

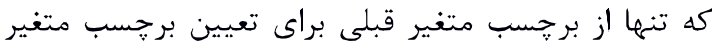

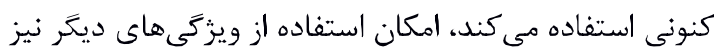

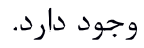

در [19] از روش ميدانهاى تصادفى شرطى براى

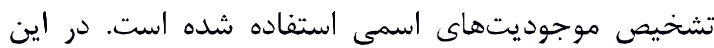
روش، تمامى برجسبهاى خروجى با درنظر گرفتن كل ورودى

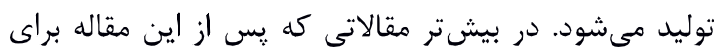

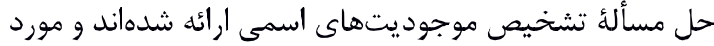

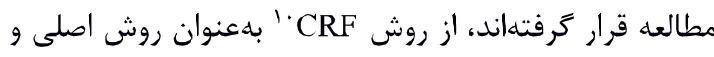
يايهاى استفاده شده است.

در هر سه روش مطرحشده از فرض سادهسازى ماركف

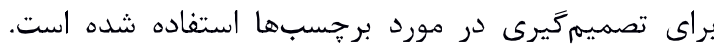

${ }^{6}$ https://catalog.ldc.upenn.edu/LDC2005T09

${ }^{7}$ sequence

${ }^{8}$ Hidden Markov Model (HMM)

9 Maximum Entropy Markov Model

${ }^{10}$ Conditional Random Fields
زبان فارسى و با استفاده از روشهاى موجود در زبان انكَليسى به طراحى سامانهاى كارآمد براى تشخيص موجوديتهاى رانى

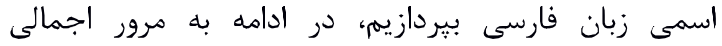

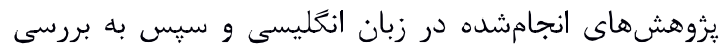

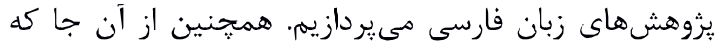

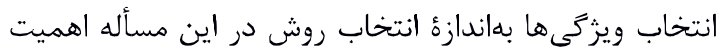
دارد، هر بخش را به دو زيربخش تقسيم مى كنيه. در زيربخش

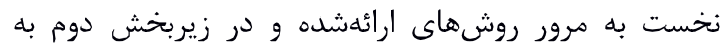

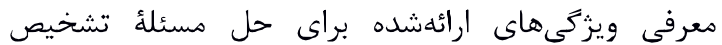
موجوديتهاى اسمى مى يردازيهم.

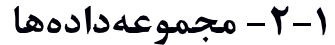
در [25] نشان داده شده كه سامانئ تشخيص موجوديتهاى

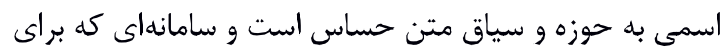

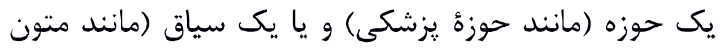

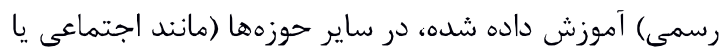

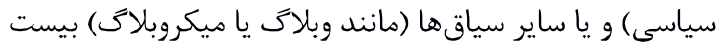

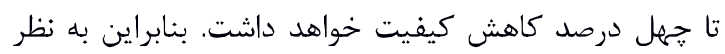

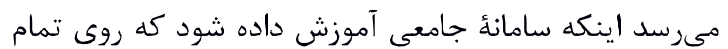

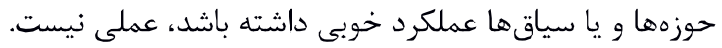
با اين وجود انتخاب متون خبرى از اين جهت كه دربركيرندأ حوزههاى متعددى از متون در سياق رسمى است، بهنظر إنظر

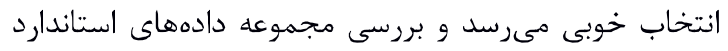

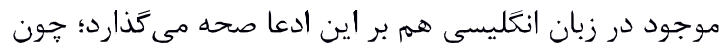

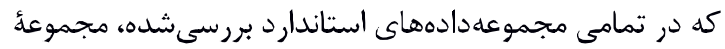
متون از متون خبرى انتخاب شدهاند. در مجموعهدادة 'CoNLL2003 [30] كه براى دو زبان

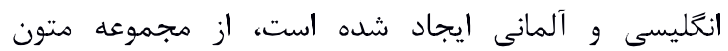

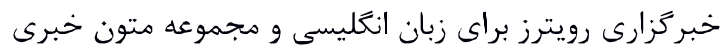

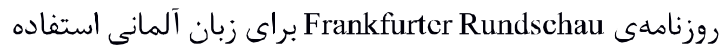

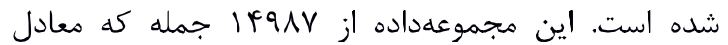

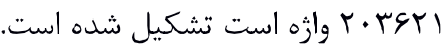

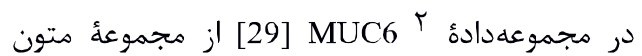

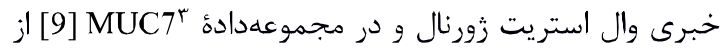
مجموعه خبر هاى موجود در نيويور كتايمز استفاده شده است.

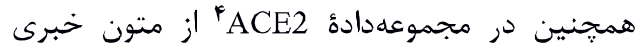

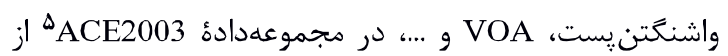

\footnotetext{
${ }^{1}$ http://www.clips.uantwerpen.be/conl12003/ner/

2 https://catalog.ldc.upenn.edu/LDC2003T13

${ }^{3} \mathrm{https}: / /$ catalog.ldc.upenn.edu/LDC2001T02

${ }^{4} \mathrm{https}: / /$ catalog.ldc.upenn.edu/LDC2003T11

${ }^{5} \mathrm{https} / / /$ catalog.ldc.upenn.edu/LDC2004T09
} 
اين مقاله ويزگى هاى هايه را به شش دستهُ وازه (نمايش

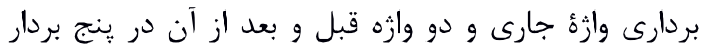

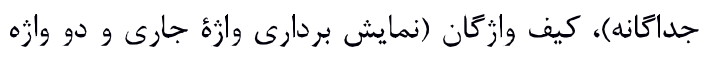

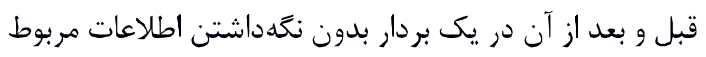

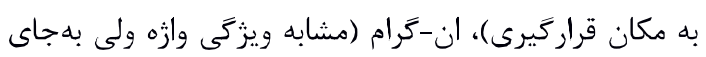

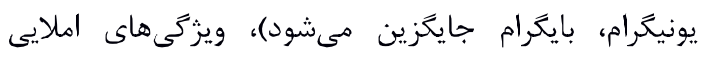

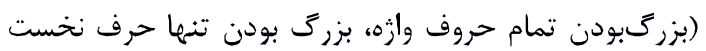

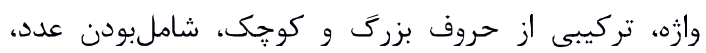

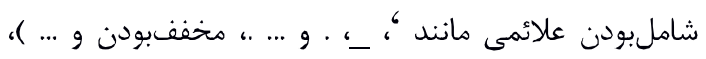

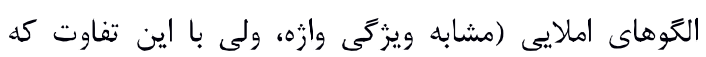

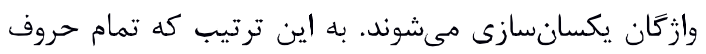

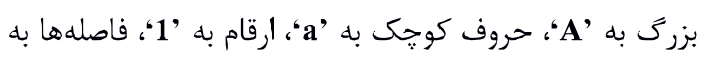

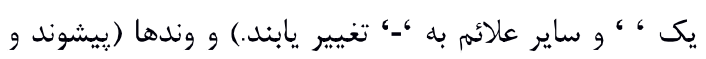

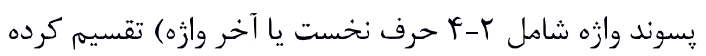

در [23] ويزگكىها به سه دسته تقسيم شدهاند كه در

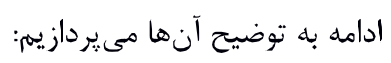

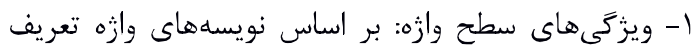

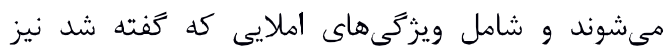

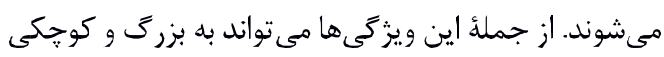

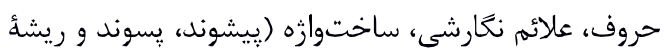

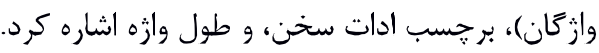

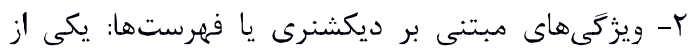

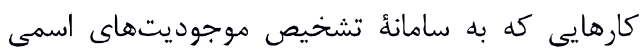

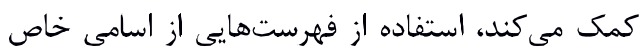

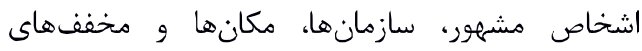

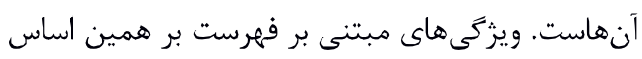

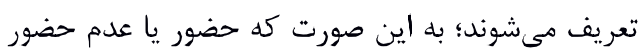

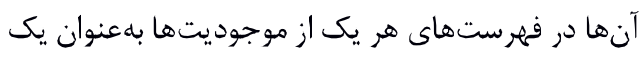

$$
\text { ويزگى در نظركرفته مىشود. }
$$

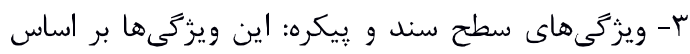

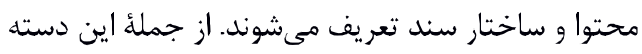

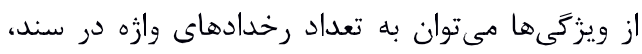

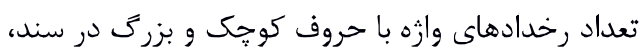

$$
\text { و محل قراركيرى در جمله اشاره كرد. }
$$

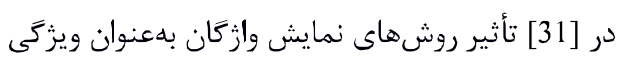

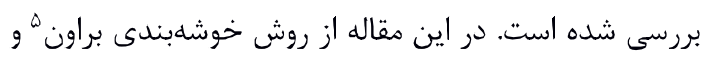

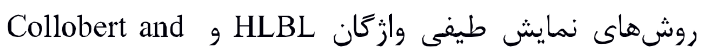

\footnotetext{
${ }^{4}$ Recurrent Neural Network (RNN)

${ }^{5}$ Brown clustering
}

فرض ماركف بيان مىكند كه برجسب هر متغير تنها به جند

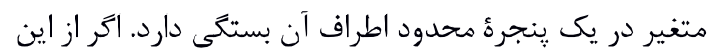

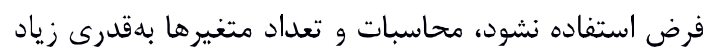

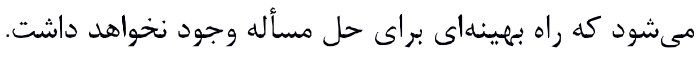

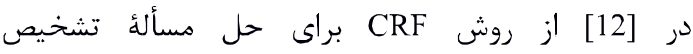
موجوديتهاى اسمى استفاده شده است؛ ولى براى آن كه

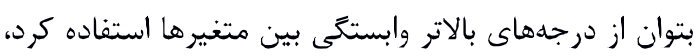
از روش نمونهبردارى گيبس استفاده كرده است. بر خلاف بيشتر مقالات كه از روش ميدانهاي تصادفى شرطى براى تشخيص موجوديتهاى اسمى استفاده ميى كنند، در [28] از روش ردهبندى بردار يشتيبان (SVC') خطى به اين منظور استفاده شده است. در سالهاى اخير با ظهور شبكههاى عصبى عميق،

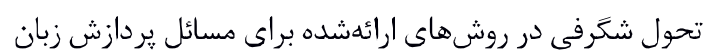

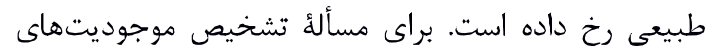

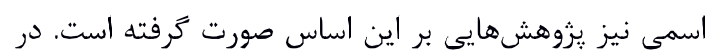

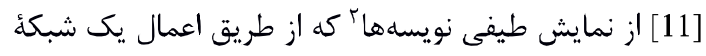

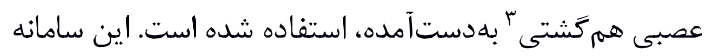

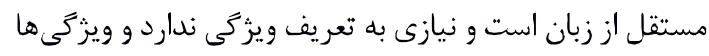
را بلصورت خودكار يادگيرى مى كند.

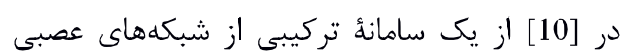

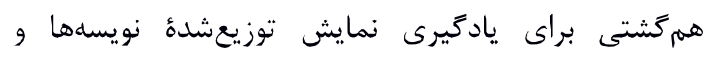

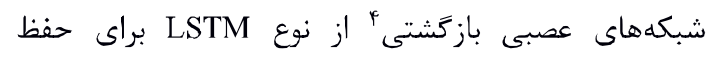
وابستكى هاى طولانى بين واثرًان استفاده شده است.

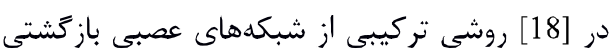
و ميدانهاى تصادفى شرطى استفاده شده است. با استفاده از

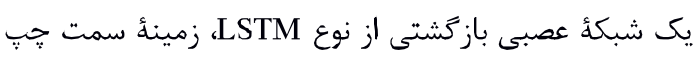
و راست وازكان مدل مىشود؛ سيس از تركيب آنها زمينه

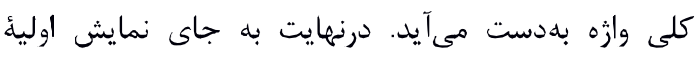
عبارات، الكوريتم ميدانهاى تصادفى شرطى بلى روى نمايش

$$
\text { حاصل از اين تركيب اعمال مىشود. }
$$

\section{د}

در [15] مجموعة خوب و جامعى از ويزگى ها ي يشنهاد شده

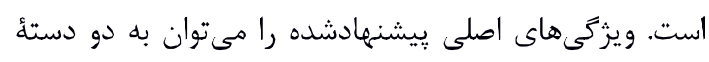

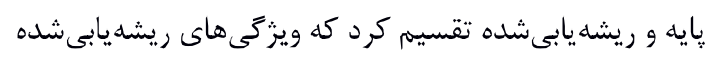

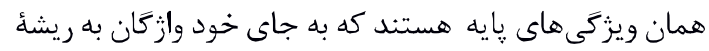

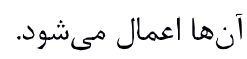

\footnotetext{
${ }^{1}$ Support Vector Classification

2 character embedding

${ }^{3}$ Convolutional Neural Network (CNN)
} 
(تركيب قاعدهمحور و يادگيرى ماشين). آنها سامانه خود را أن

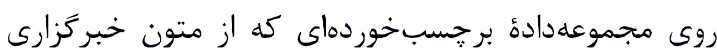
مهر ساختهاند، مورد آزمون قرار دادهاند.

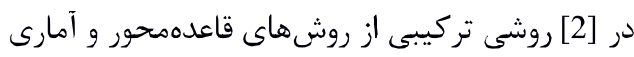

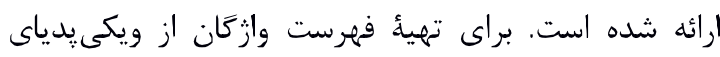

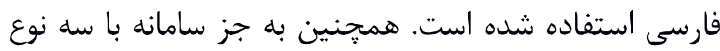
بر קسب موجوديت اسمى (شخص، مكان و سازمان) از سامانه

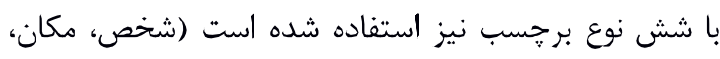

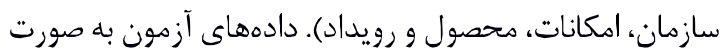

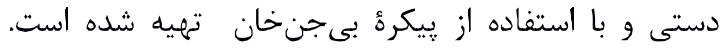

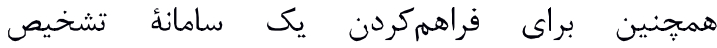
موجوديتهاى اسمى مبتنى بر يادكيرى ماشين، بلصورين

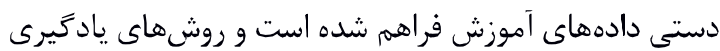
ماشين مورد آزمون قرار كرفته كه بهترين مدل ارائهشده مدل مبتنى بر ميدانهاى تصادفى شرطى بوده است. در [3] تأثير

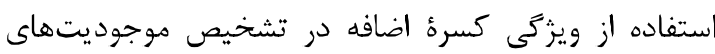

$$
\text { اسمى مورد بررسى قرار گرفته است. }
$$

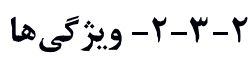

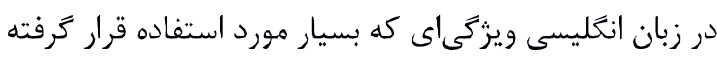

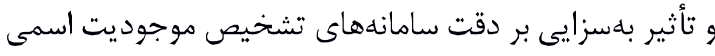

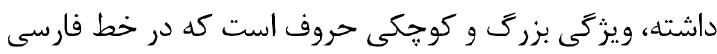

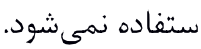

در زبان فارسى ويزگى كسرة اضافه وجود دارد كه مى تواند مشخص كننده خوبى براى مرز عبارتهاى مورئ موجوديت

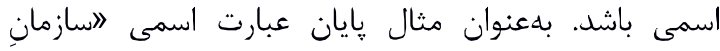

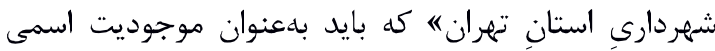

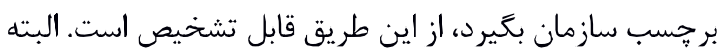
دقت تشخيص كسرة اضافه صددرصد نيست و مى تواند با خطا

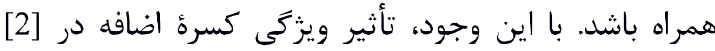

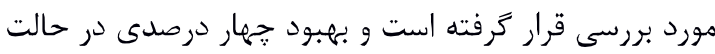

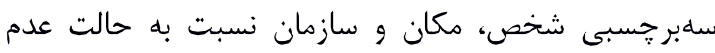

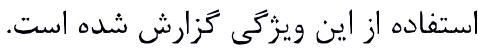

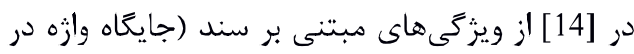

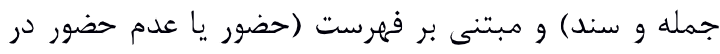

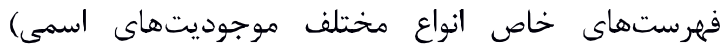

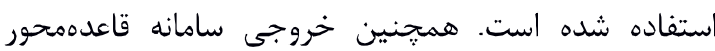

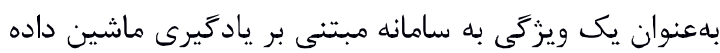

استفاده شده است. با بررسى روشهاى مختلف Weston

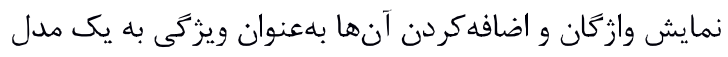

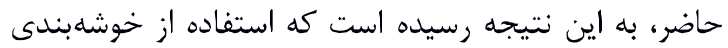

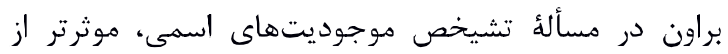

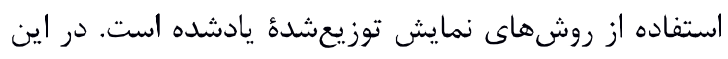

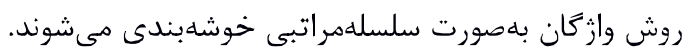
در [21] از اين روش براى ردهبندى واءثًان در طبقات

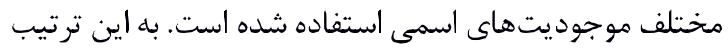

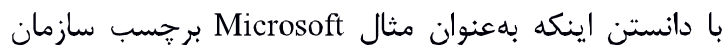

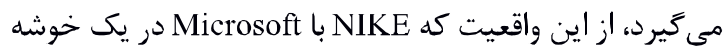

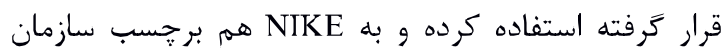
تخصيص مى دهد. در [27] نيز روشهاى مختلف نمايش توزيعشده براى

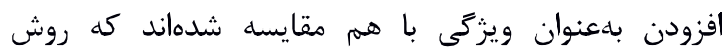

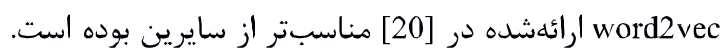

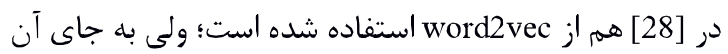
كه نمايش توزيعشده بهصورت مستقيم بهعنوان ويثگى به به كار رود، نمايشهاى توزيعشده خوشهبندى شده و شمارئ خوشأ

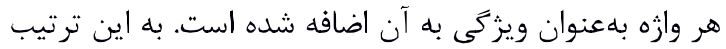

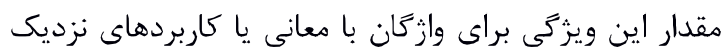
به هم مشابه خواهد بود.

\section{r-r-r-r - بزوهشها در زبان فارسى}

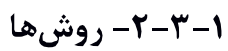

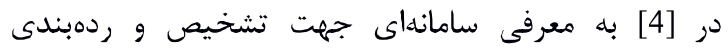

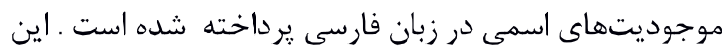

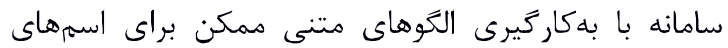

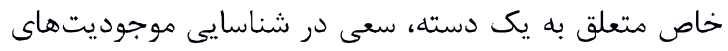

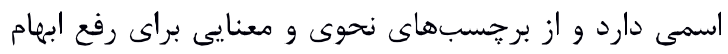

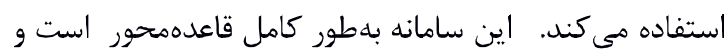
از روشهاى يادگيرى استفاده نمى كند.

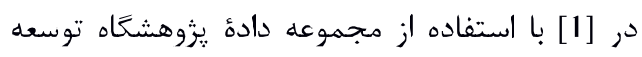

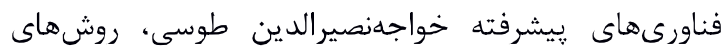

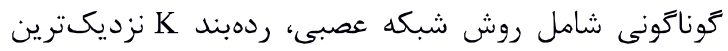

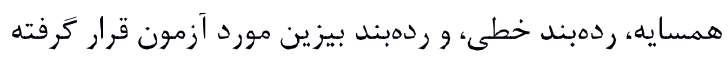
و نشان داده شده است كه ردهبند خطى بهترين و ردهبند ردبند مبتنى بر شبكه عصبى بدترين نتيجه را از نظر معيار F1 دارند.

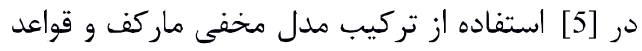

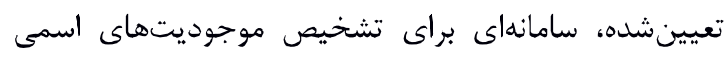
ييشنهاد شده است. درواقع اين سامانه از نوع تركيبى است تودئ 
برجسب مى گيرند. بلعنوان مثال 》افرود

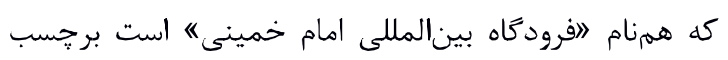

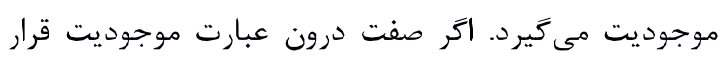

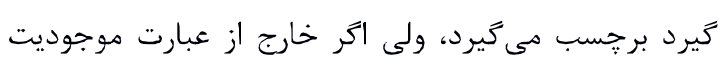

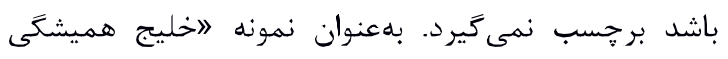
فارس" دركل يك برجسب مكان مى تيرد، ولى دلى در "اسيد

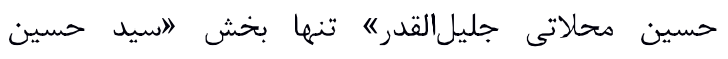

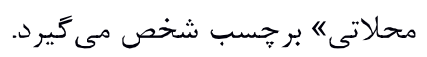

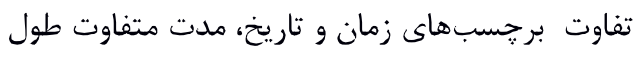

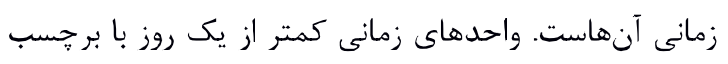

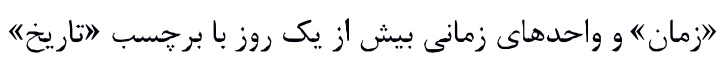

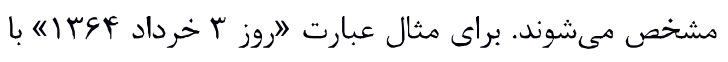

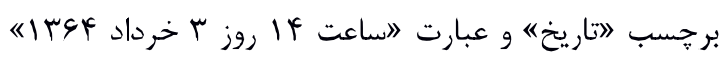
با برجسب "زمان" مشخص مئشود.

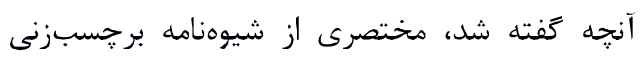

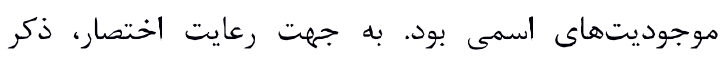

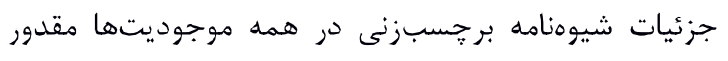

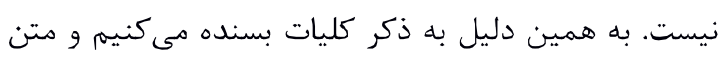

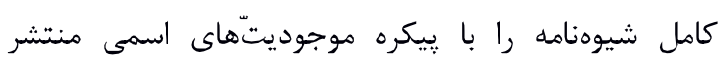

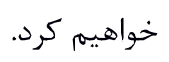
برحسبزن هاى اين ييكره داراى تحصيلات كارشناسى

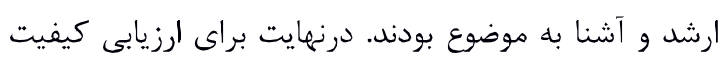

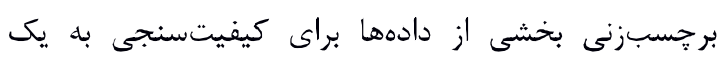

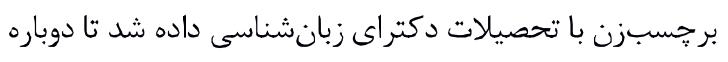
بر حسبزنى شود.

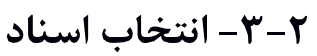

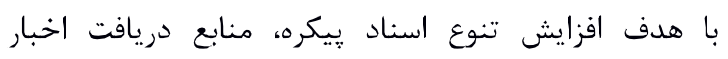

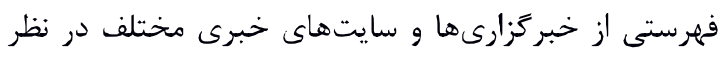

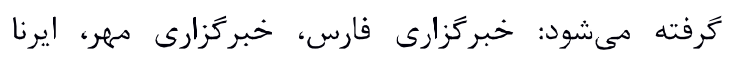

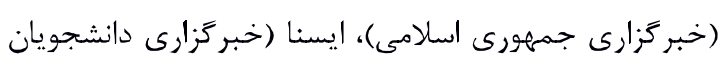

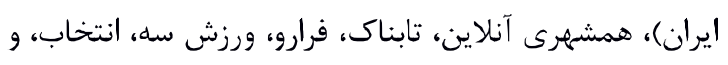

$$
\text { باشكاه خبرنغاران جوان. }
$$

انتخاب اسناد مجموعهداده از بين تعداد باد بسيار زياد

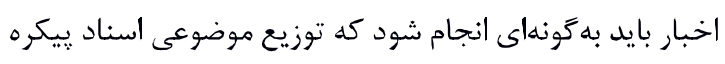

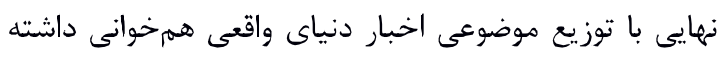

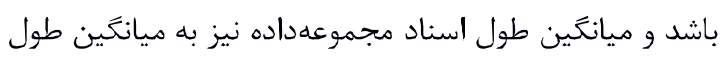

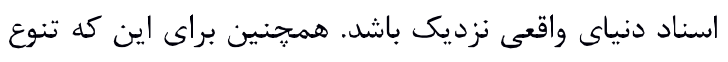

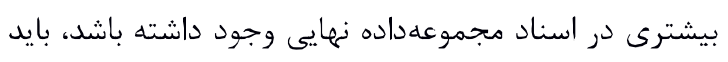

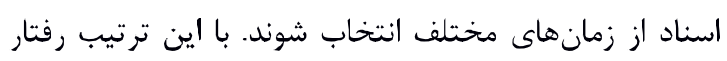
اسناد ييكره به اخبار دنياى واقعى نزديكتر مخى شود.
در [1] از نقش دستورى كلمهٔ قبل و بعد، طول وازه،

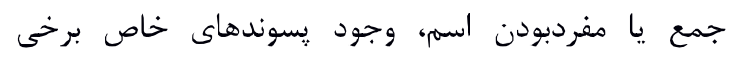

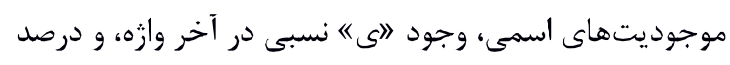

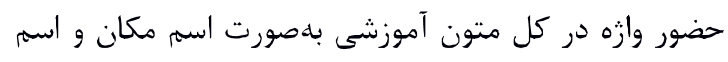
خاص شخص استفاده شده است.

\section{ب - بيكره}

در اين بخش فرآيند توليد بيكرة موجوديتهاى اسمى ارائه

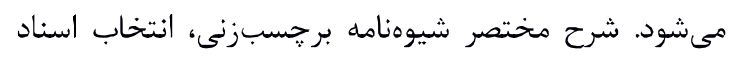

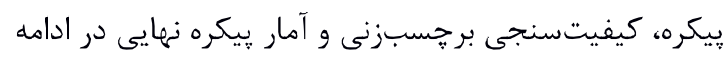

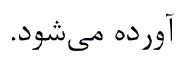

\section{- 1- - شيوهنامه}

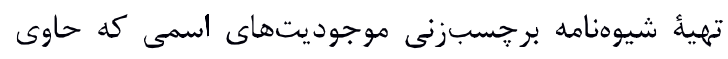

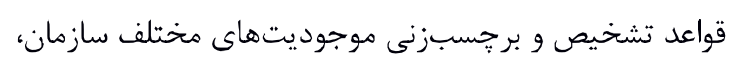

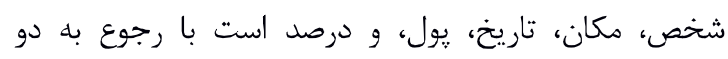

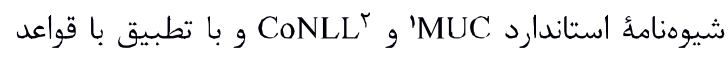

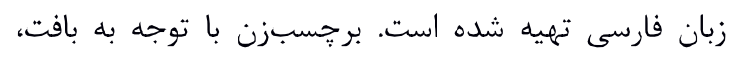

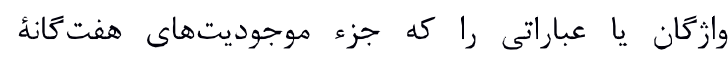

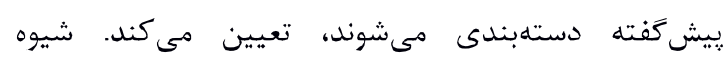

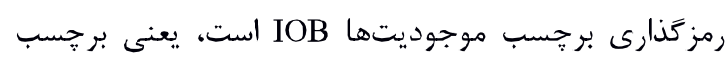

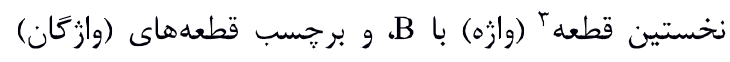

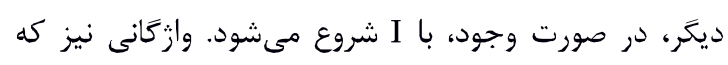
موجوديت نيستند، برجسب O

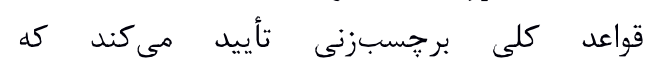

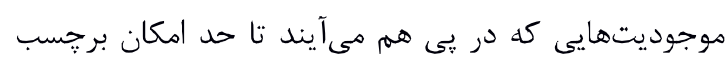

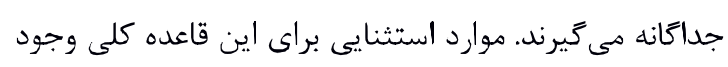

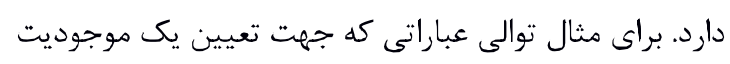

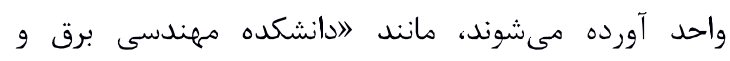

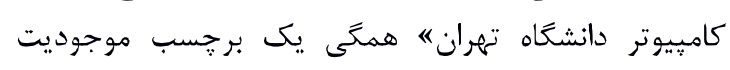

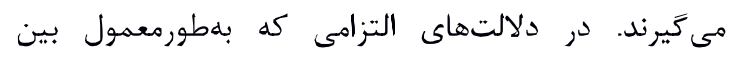

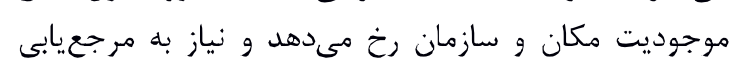

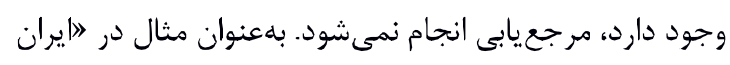

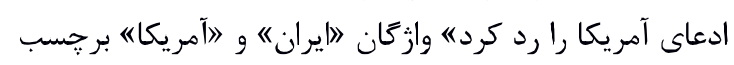

$$
\text { مكان مى كيرند. }
$$

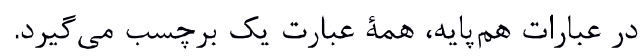

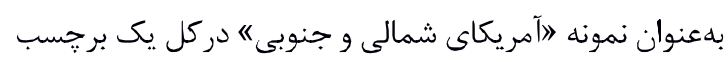

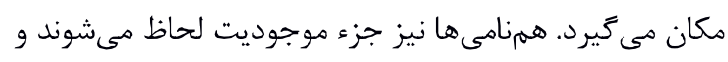

${ }^{1}$ wwwnlpir.nist.gov/related_projects/muc/proceedings/ne_ta sk.html

2 www.cnts.ua.ac.be/conll2003/ner/

${ }^{3}$ token 
برجسب ها محاسبه مىشود. از اسناد مجموعهدادة . •19 سند

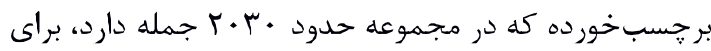

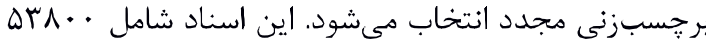

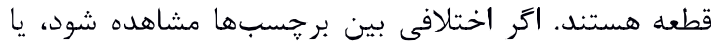

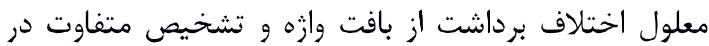
نوع موجوديت است يا اشتباهى توسط يكى از برجسبز بـن إنها

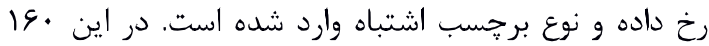

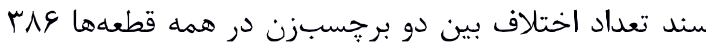

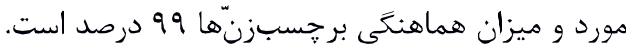

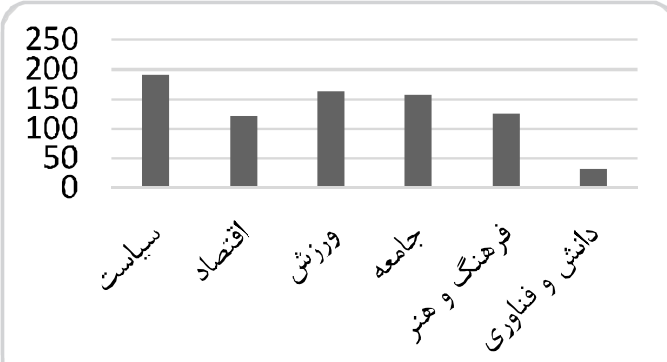

(شكل - () : تعداد اسناد انتخابى در موضوعات مختلف (Figure-1): Number of selected documents per topic

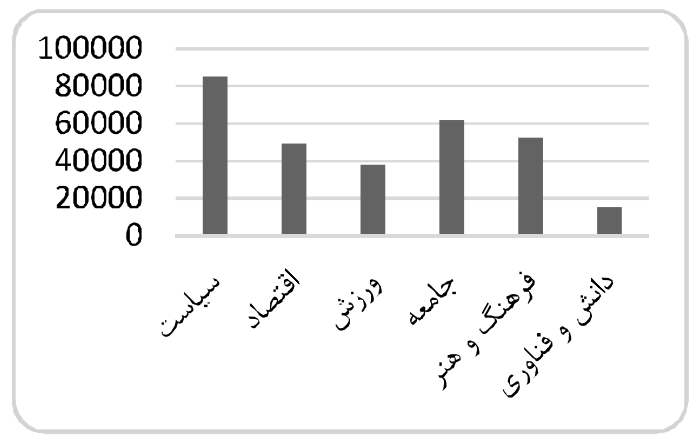

(شكل-Y): تعداد وازمها در اسناد انتخابى در موضوعات مختلف (Figure-2): Number of words in selected documents per topic

با توجه به اينكه درصد بالايى از قطعهها موجوديت

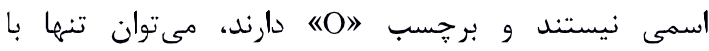
لحاظكردن قطعههايى كه برجسب موجوديت دارند نيز درصد اختلاف را بررسى كرد؛ جون هيج مرجع مطلقى براى تعيين

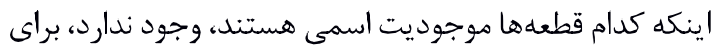
محاسبه تعداد قطعههايى كه موجوديت اسمى هستند، اجتماع

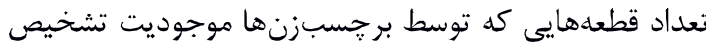

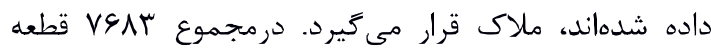

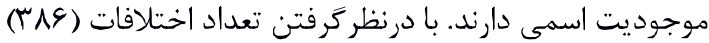

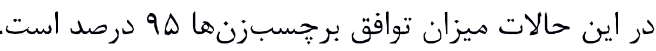
همجنين معيار كايا براى محاسبه ميزان توافق بين

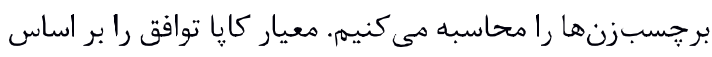

براى انتخاب اسناد مجموعه داده ابتدا نياز است، اسناد

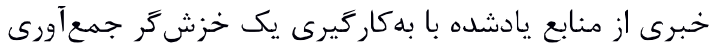

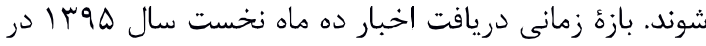

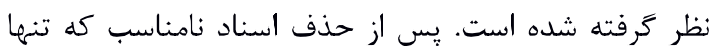
شامل تصاوير يا متنهاى بسيار كوتاه هستند (زير هفتاد إد

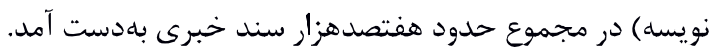

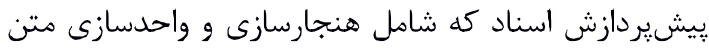
است با ابزار Persianp' صورت كرفته است. براى تعيين موضوع اسناد از سامانئ ردهبند موضوعى

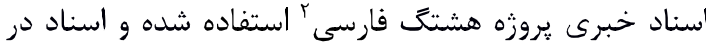

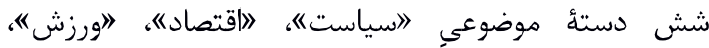

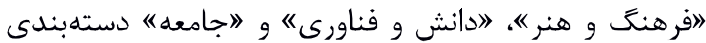
مى شوند.

در هر موضوع ميانگين طول و انحراف معيار اسناد

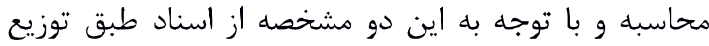

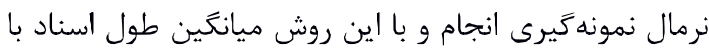

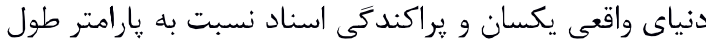
نيز حفظ مىشود؛ سيس در بازههاى زمانى مختلف بـ بهصورت

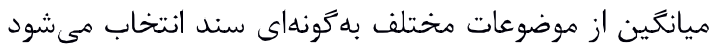
كه توزيع موضوعى اسناد انتخابى با توزيع موضوعى همد اسناد مورياد برابر باشد.

براى اينكه ييكره درنهايت شامل اسنادى از منابع مختلف خبرى باشد، از هر منبع خبرى به نسبت اخبارى كه

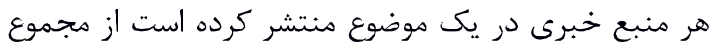

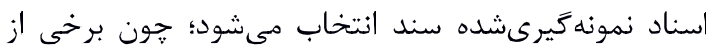
خبركزارىها اخبار بسيار بيشترى نسبت به ديخر خبركزارى ندها

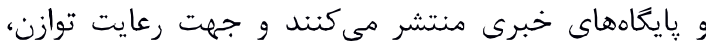

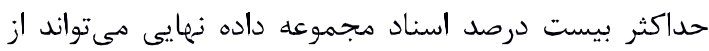
يك منبع خبرى باشد. تنها مورد استثنا، سايت ورزش سه است كه جون اختصاص به ورزش دارد سى دئ درصد اسناد ورزشى را به خود اختصاص ميى دهدي. به اين ترتيب يِكره نهايى شاهل اسنادى است كه از

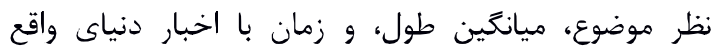
همخوانى دارد. شكل (1) نمودار تعداد اسناد را در موضوعات

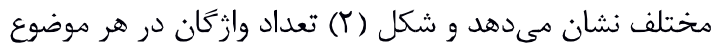
را مشخص مى كند.

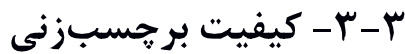

براى اينكه برجسبزنى كيفيتسنجى شود، بخشى از يريكره

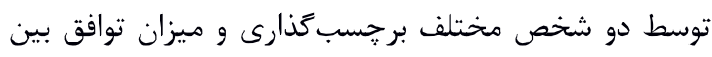

${ }^{1}$ persianp.ir

${ }^{2}$ http://pclp.itrc.ac.ir/?q=products\&page=8( (رده4 رديف) 


\section{|}

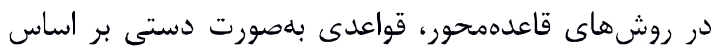

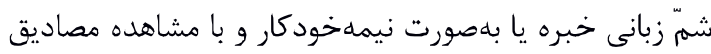

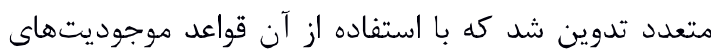
اسمى متن تشخيص داده شود. قواعد به دو كونه قواعد منظمه

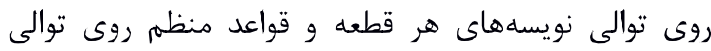
قطعههاى متن است. بهعنوان مثال موجوديت تاريخ (مانند • ل نويسههاى قطعه تشخيص داد. قواعد منظهم روى توالى قطعهنها

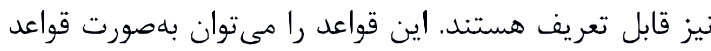

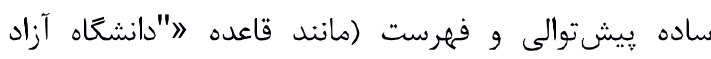

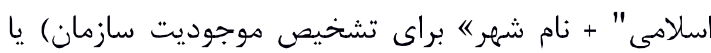

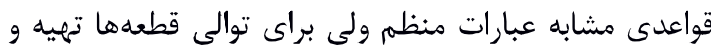
براى تشخيص موجوديتها استفاده كرد.

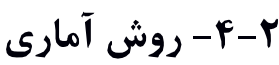

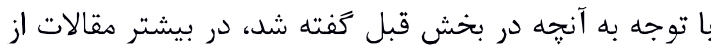

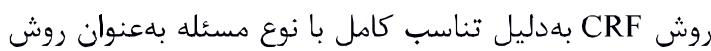

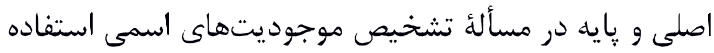

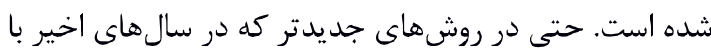

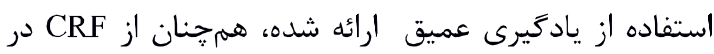

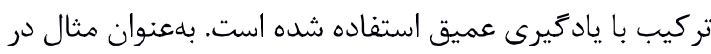

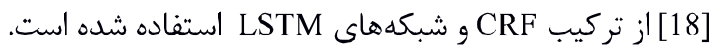

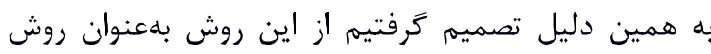

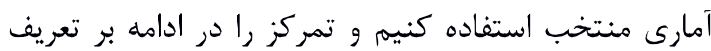

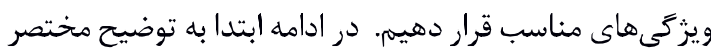

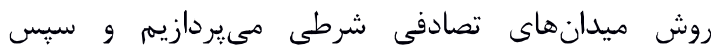
ويزّكى هاى مورد استفاده را معرفى مى كنيم.

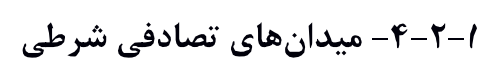

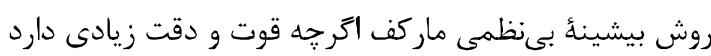

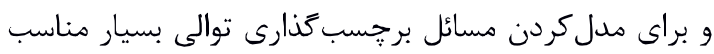

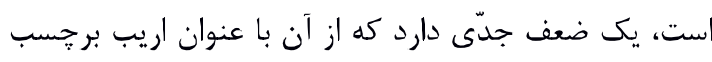

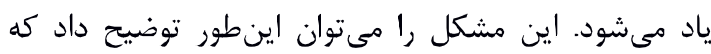

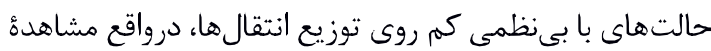

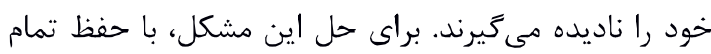

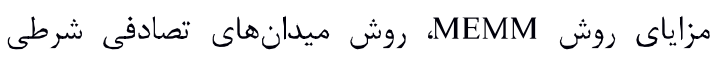
ارائه شده است. در شكل (r) (CRF) CRF و د MEMM‘HMM است. همانطور كه در اين شكل مشخص است، در روش دان داده
ميزان فاصله رأى برجسبزنها نسبت به حالتى كد

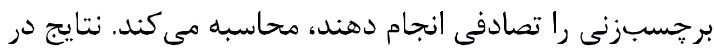

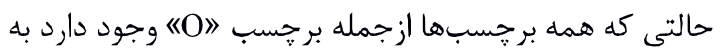

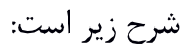

Kappa $=0.9723 ; 95 \%$ CI: 0.9695 to 0.9750 p-value $<2.2 \mathrm{e}-16$

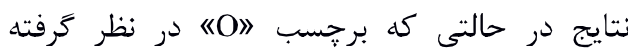
نمىشود به شرح زير است:

Kappa $=0.9409 ; 95 \%$ CI: 0.9352 to 0.9467 p-value $<2.2 \mathrm{e}-16$;

همان طور كه مشاهده مىشود، ميزان p-value در هر دو حالت بسيار يايين است و نتيجه حكايت از توافق بالا بين هين بر جسبزن ها دارد.

\section{ـ}

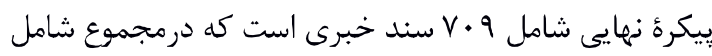

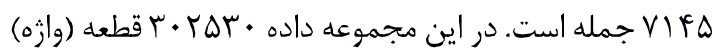

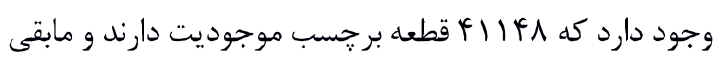

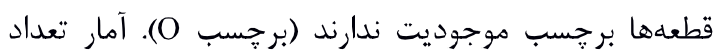

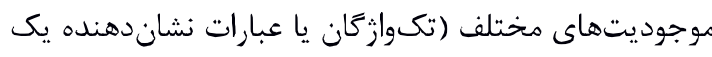

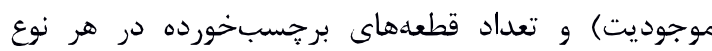
موجوديت در جدول (1) آمده است. براى محاسبة تعداد موجوديتهاى يكتا هر موجوديت تنها يك بار شمرده و تكرارهاى مختلف آن ناديده كرفتئه مىشود.

(جدول -1) تعداد قطعهاى برجسبخورده در هر نوع موجوديت (Table-1) Number of labeled tokens per entity type

\begin{tabular}{|c|c|c|c|}
\hline موجوديتهاى يكتا & قطعدهاد & موجوديت & موجوديت \\
\hline 2507 & 7675 & 4447 & شخص \\
\hline 2413 & 16964 & 6360 & سازمان \\
\hline 1288 & 8782 & 6223 & مكان \\
\hline 801 & 732 & 281 & زمان \\
\hline 157 & 4259 & 1858 & تاريخ \\
\hline 436 & 2037 & 527 & مبالغ مالى \\
\hline 179 & 699 & 326 & درصد \\
\hline 7781 & 41148 & 20022 & تعداد كل \\
\hline
\end{tabular}

\section{F}

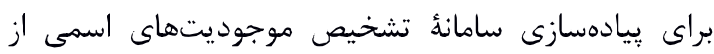

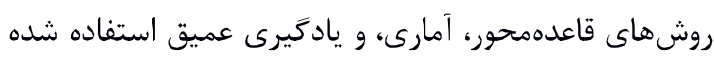

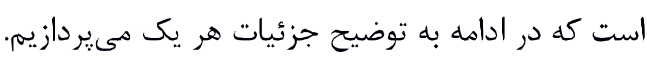


همجنين هجموعهاى غنى از ويزّكى ها بهصورت بيشفرض براى آن تعريف شدهاند و بلهادگى قابل استفاده هستند. علاوهبراين در بسيارى از مقالات از همين سامانه بهعنوان

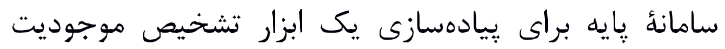

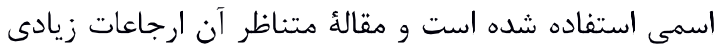
دارد. - n

براى استخراج ويزگى هاى بنوازه، برجسب عبارت اسمى، و برجسب ادات سخن از ابزار Persianp استفاده شده بئ ورئ

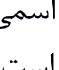

هر حالت، تنها با توجه به حالت قبلى توليد و مشاهدهها از حالتها توليد و در MEMM، هر حالت باتوجه به حالت قبلى و مشاهدة كنونى تعيين مىشود. در CRF، كل توالى حالتها از كل توالى مشاهدات توليد مىشود و به همين علت مانند روش MEMM دجار سوگيرى روى تعداد حالتهاى خروجى از هر حالت نمىشود. گروه يردازش زبان

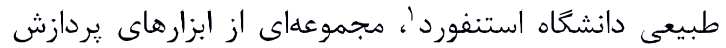

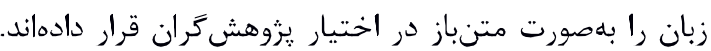

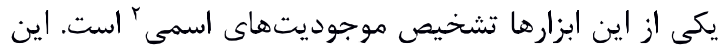

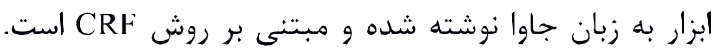

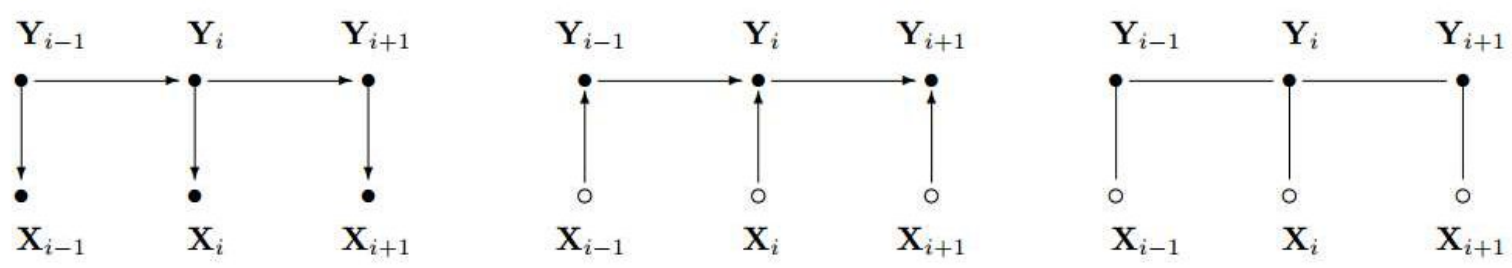

(شكل -Y): تفاوت روش هاى CRF و. MEMM،HMM. بركرفته از [17] . در شكل سمت جب HMM، در وسط MEMM و در سمت

راست CRF نمايش داده شده است.

(Figure-3): Difference between HMM (left), MEMM (middle), and CRF (right) methods [17]

از ويزّى بنوازه نيز علاوهبر خود وازه استفاده كرديم. علاوهبر اينها استفاده از ويزخى هاى مبتنى بر ديكشنرى نيز كاربردى است؛ بدينترتيب فهرستى از موجوديتهاى اسمى بدون ابهام

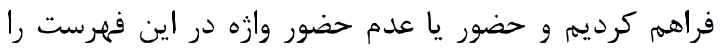
باعنوان ويثزى در نظر گرفتيم. براى تهينٔ اين فهرستها ابتدا

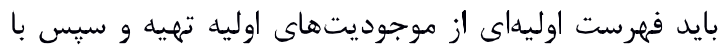

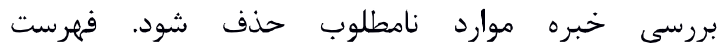
موجوديتهاى اسمى مورد استفاده در اين زيروهش، از مرون

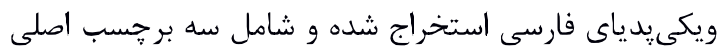
شخص، مكان و سازمان است. در اين فهرست، تعداد موجوديت شخص، مجر FNY موجوديت مكان و و موجوديت سازمان وجود دارد. به اين ترتيب ويزخى هاى مورد استفاده از اين قرار

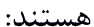

•وازرٔ جارى و يك وازئ قبل و يكى وازئ بعد از آن

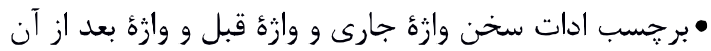

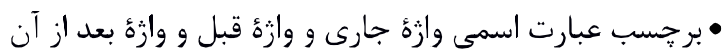

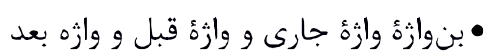

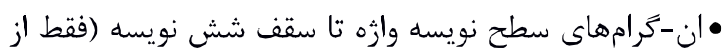

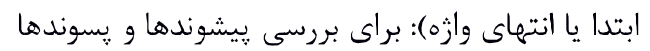

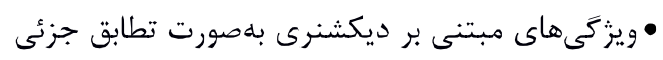

r ويزگى هايى كه ما براى آموزش سامانه CRF استفاده كردهايم،

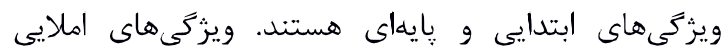
تعريفشده در مقالات انعليسى بهصورت مستقيم برايى فارسى قابل استفاده نيست و بايد براى زبان فارسى بازتعريف شوند.

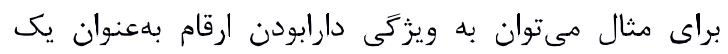
ييشفرض براى تعلق وازه به دسته موجوديتهاى اسمى

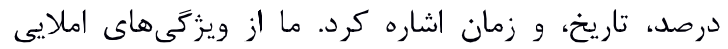

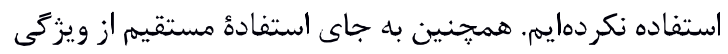

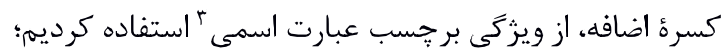
جون موجوديتهاى اسمى بهطورمعمول يكى عبارت اسمى

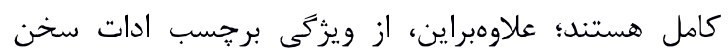

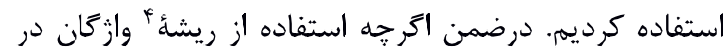
ثروهشهاى بازيابى اطلاعات مفيد است، در ساير كارهاى

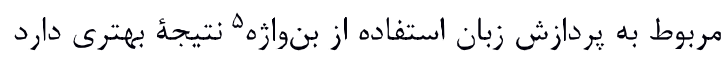

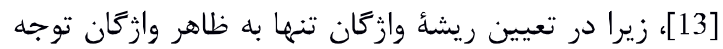
مىشود در حالى كه در تعيين بنوازه به سطح معنايى وازگًان

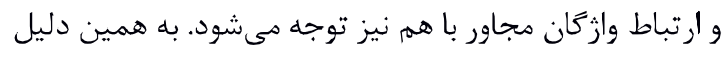

\footnotetext{
${ }^{1}$ https://nlp.stanford.edu

${ }^{2}$ https://nlp.stanford.edu/software/CRF-NER.html

${ }^{3}$ NP-Chunk

${ }^{4}$ stem

${ }^{5}$ lemma
} 
نيازى به تعريف و استخراج ويزگى ها نيست و شبكة عصبى

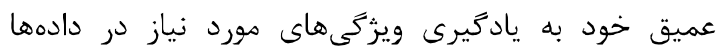

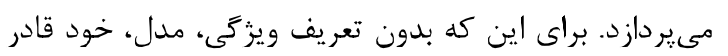

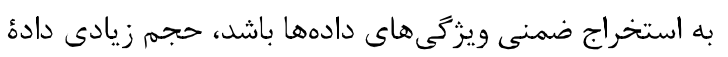

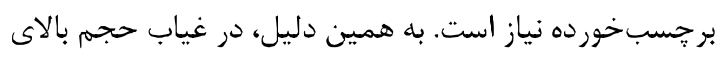

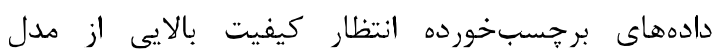

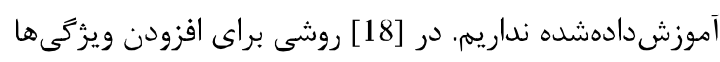

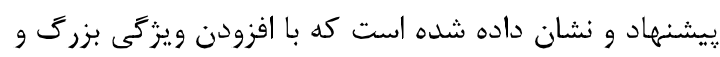

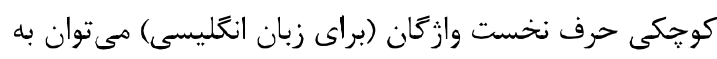

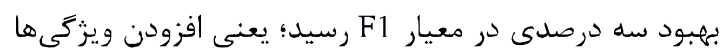

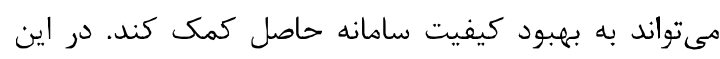

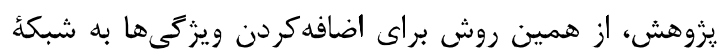

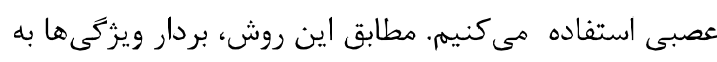

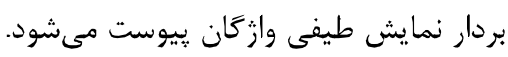

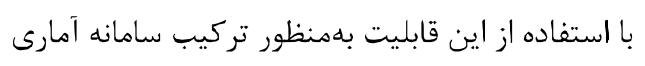

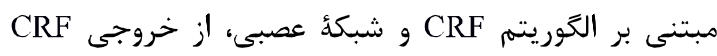

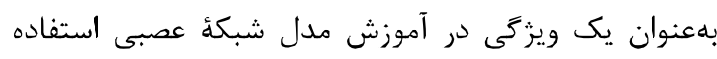

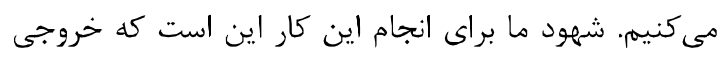

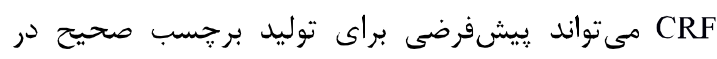

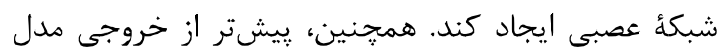

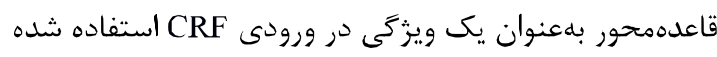

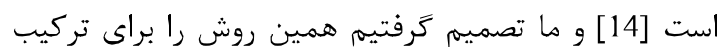
و CRF

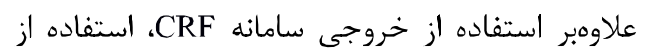

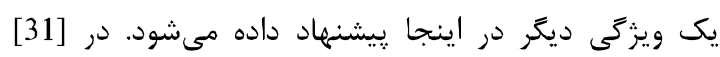

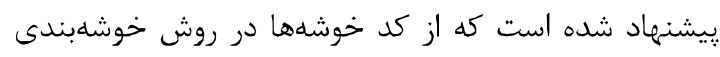

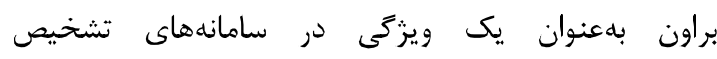

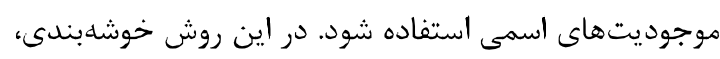

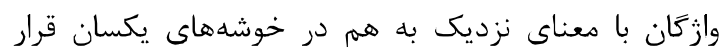

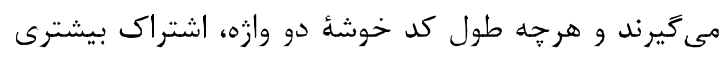

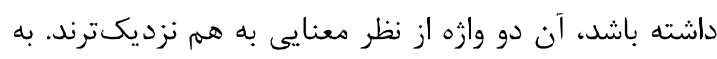

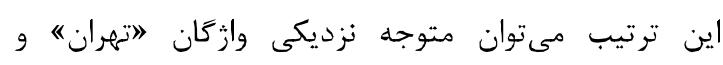

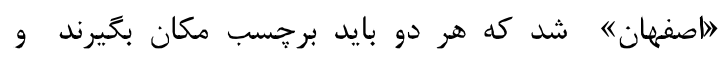

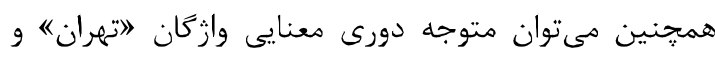

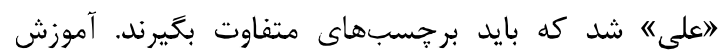

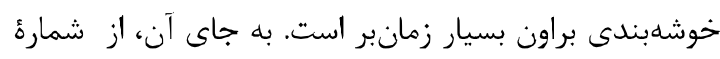

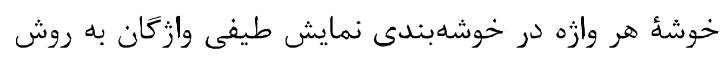

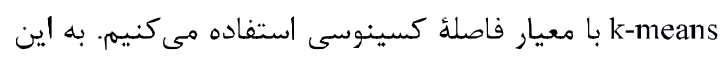

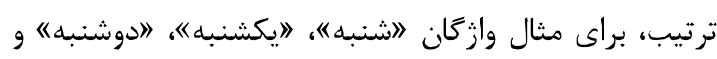

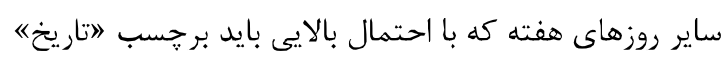

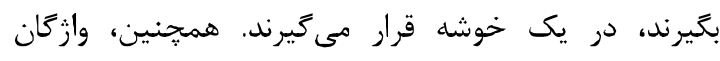

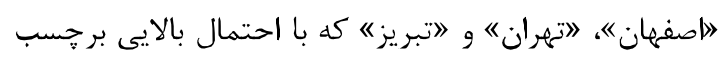

\section{ب-}

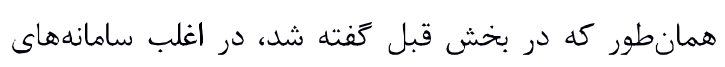

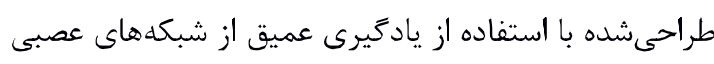

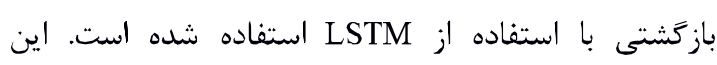

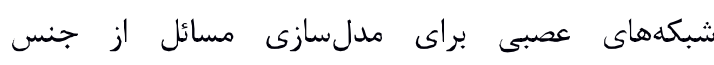

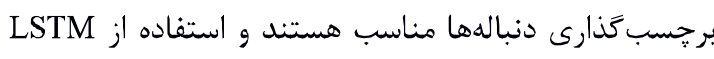

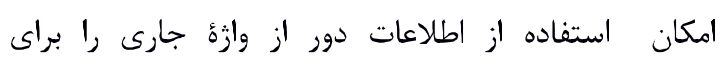

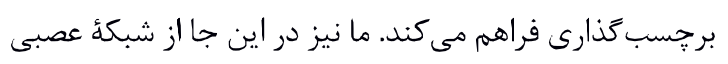
با استفاده از LSTM استفاده كردهايهم.

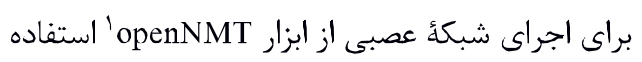

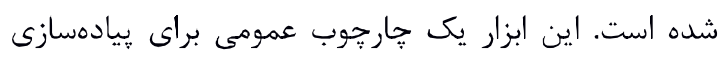

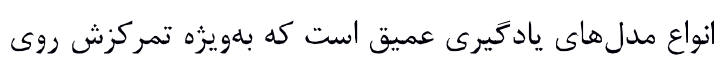

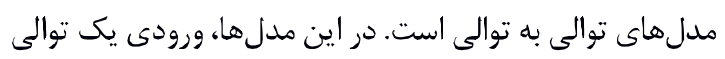

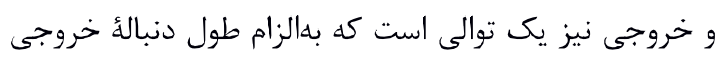

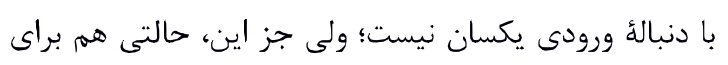

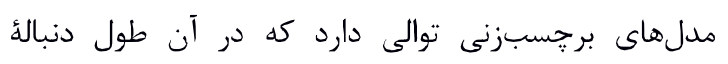

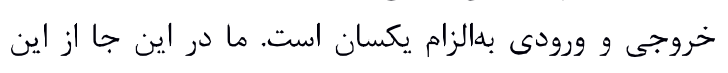

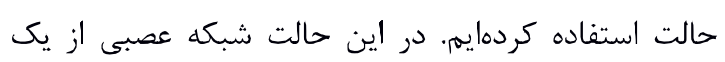

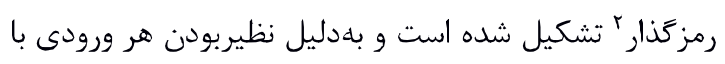

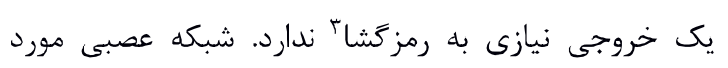

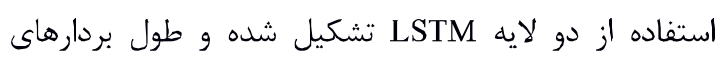

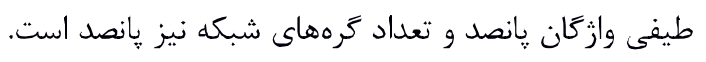

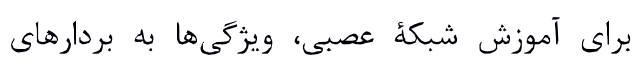

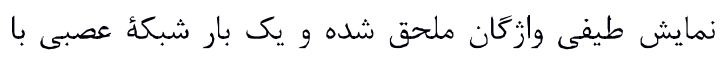

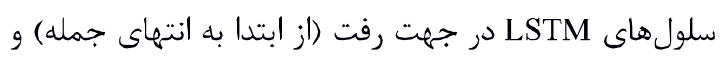

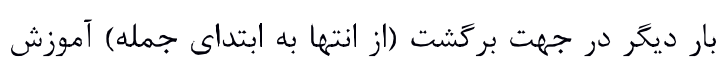
داده مىشود.

براى خوشهبندى بردارهاى نمايش طيفى وازٔمان جهت

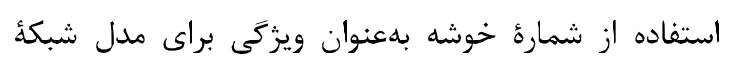

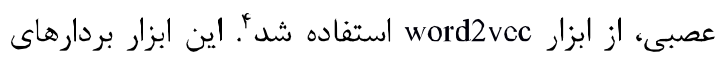

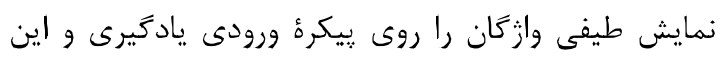

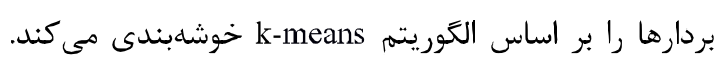

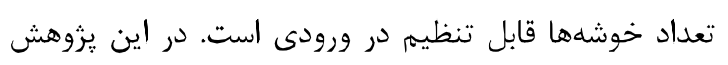
تعداد خوشهها برابر ·لها قرار داده شده است.

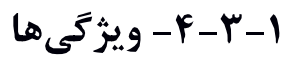

بلطورعمومى در روشهاى مبتنى بر شبكئ عصبى عميق

\footnotetext{
${ }^{1}$ http://opennmt.net

2 encoder

${ }^{3}$ decoder

${ }^{4}$ https://github.com/dav/word2vec
} 


$$
\text { فراخوانى × دقت ×1 }
$$

دقت، مشخص كنندهٔ درصد موجوديتهاى اسمى است

كه توسط سامانه بهدرستى تشخيص داده شدهاند و فراخوانى، درصد موجوديتهاى اسمى واقعى است كه سامانه توانسته

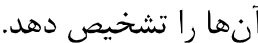

وقتى دقت در سطح عبارت محاسبه مىشود، مرز دقيق

عبارت موجوديت اسمى مهمم است و حتى اكر يك وازه از آن

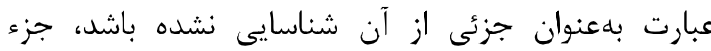
تشخيصهاى درست لحاظ نمىشود. بهعنوان مثال در عبارت ادانشكده مهندسى برق و كاميّوتر دانشكدة فنى دانشعاه تهرانه كافى است كه يك وازه (براى مثال دانشكده) بهعنوان جزئى از موجوديت، برجسب نخورده باشد. در اين صورت حتى

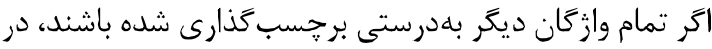

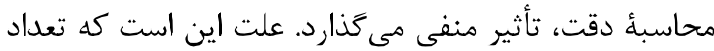
تشخيصهاى درست ثابت مىماند؛ اما تعداد كل تشخيصها مانى افزايش و به اين ترتيب دقت كاهش مى ديابد. بنابراين تشخيصندادن يك موجوديت اسمى طولانى از نظر محاسبة. دقت در سطح عبارت به تشخيص ناقص آن ارجحيت دارد. از

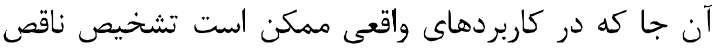
موجوديت اسمى هم كاربرد داشته باشد و نيازى به تشخيص صددرصدى آن نباشد، در اين يزوهش دقت در سطح وازه را هم كزارش كردمايم.

\section{r-1 - ارزيابى بخش هاى مختلف سامانه}

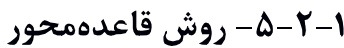
براى تشخيص قاعدهمحور موجوديتهاى اسمى فارسى

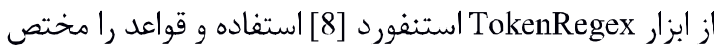
ابزار آمادهسازى مى كنيهم. نتيجة ارزيابى سامانة قاعدهمحور طراحى شده بر روى

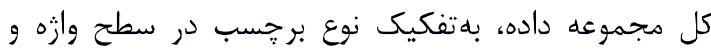
عبارت در جدول (T) و جدول (r) ززارش شده است. همان طور كه انتظار مىرفت، دقت اين سامانه تاحدودى بالا ولى فراخوانى آن پايين است.

$$
\text { r-r- }
$$

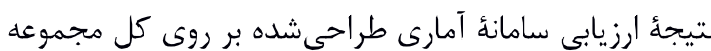
داده، بهتفكيك نوع برجسب در سطح وازيه و عبارت در

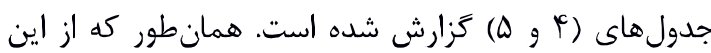

"مكان" مى گيرند، در يك خوشه قرار مى گيرند. فايده اين

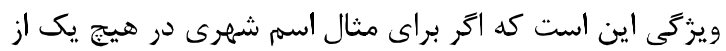

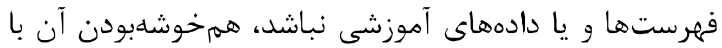

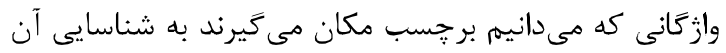
اسم بهعنوان مكان كمك شايانى مى كند؛ به اين ترتيب سامانئ

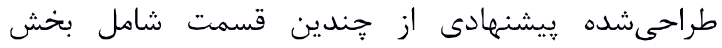
قاعدهدحور (شامل فهرستمحور و مبتنى بر عبارات منظمه)، آمارى هبتنى بر CRF، يادكيرى عميق هبتنى بر LSTM، و

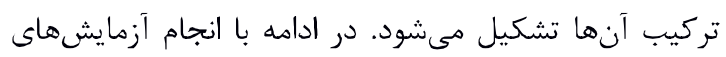
متعدد با استفاده از مجموعهداده طراحىشده به ارزيابى هر مر مركي بخش مى ميردازيم.

\section{ه- - ارزيابى}

در اين بخش ابتدا به معرفى معيارهاى ارزيابى مورد استفاده

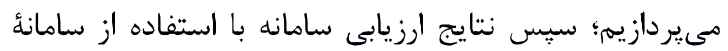

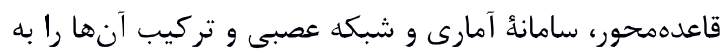
همراه تحليلى بر خطاهاى سامانُٔ نهايى ارائه مى ندهيم.

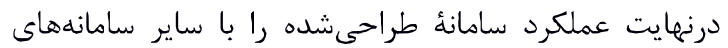
موجود كه امكان استفاده از آنها فراهم بوده مقايسه مي كنيم. k-fold cross-validation تمام ارزيابىها به روش انجام شده كه براى بخش CRF، مقدار k برابر بنج و براى

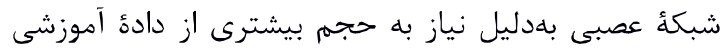
اين مقدار برابر با ده در نظر گرفته شده است. هر بار عمل

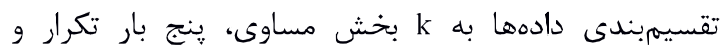
ميانگين مقدارهاى دقت، فراخوانى، و F1 تزارش شده است. براى مشخص كردن معناداربودن يا نبودن بهبودها، از آزمون مئن آمارى Student's t-test جفتى با سطح اطمينان هو مجن درصد استفاده شده است.

\section{ا-ه- - - معيار هاى ارزيابى}

براى آن كه مشخص شود عملكرد يك سامانئ طراحى شده تا

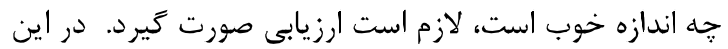
يزوهش از روش ارزيابى CONLL استفاده مى كنيه. در اين

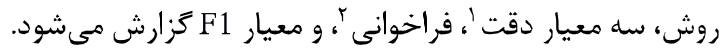

$$
\begin{aligned}
& \text { رابطة محاسبة اين سه معيار در زير آمده است: } \\
& \text { تعداد كل تشخيصهاد تشخهاى صحيح = دقت } \\
& \text { تعداد تشخيص هاى صحيح = فراخوانى }
\end{aligned}
$$

${ }^{1}$ precision

${ }^{2}$ recall 


\begin{tabular}{|c|c|c|c|}
\hline 0.74 & 0.62 & 0.91 & زمان \\
\hline 0.84 & 0.79 & 0.89 & تاريخ \\
\hline 0.90 & 0.84 & 0.98 & مبالغ مالى \\
\hline 0.95 & 0.91 & 0.98 & درصد \\
\hline 0.83 & 0.76 & 0.92 & كل \\
\hline
\end{tabular}

(جدول -ه):نتايج سامانة آمارى - سطح عبارت

(Table-5):Statistical system results - phrase level

\begin{tabular}{|c|c|c|c|}
\hline F1 & فراخوانى & دقت & نوع موجوديت \\
\hline 0.72 & 0.65 & 0.80 & شخص \\
\hline 0.82 & 0.81 & 0.82 & مكان \\
\hline 0.70 & 0.67 & 0.76 & سازمان \\
\hline 0.66 & 0.61 & 0.72 & زمان \\
\hline 0.74 & 0.71 & 0.77 & تاريخ \\
\hline 0.79 & 0.75 & 0.83 & مبالغ مالى \\
\hline 0.91 & 0.91 & 0.92 & درصد \\
\hline 0.75 & 0.72 & 0.80 & كل \\
\hline
\end{tabular}

r-Y- - - - تركيب روشهاى قاعدهمحور و آمارى

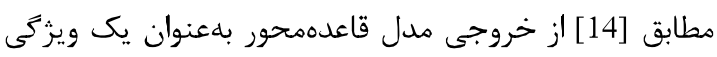

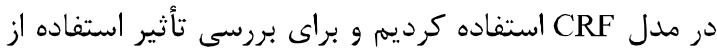

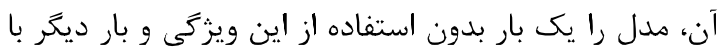

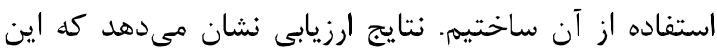

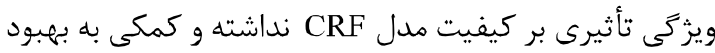

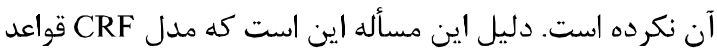

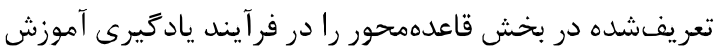

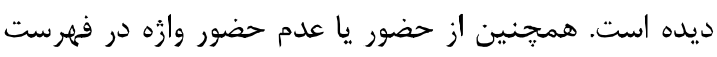

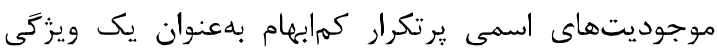

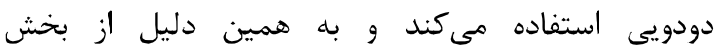
فهرستمحور هم بىنياز است.

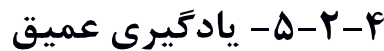

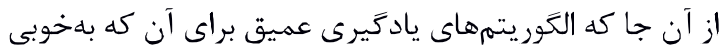

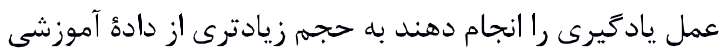

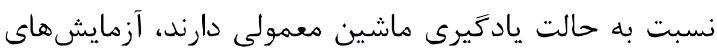

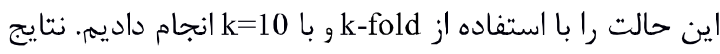

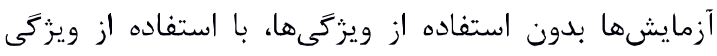

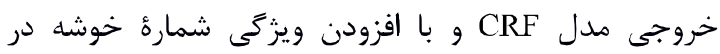

$$
\text { جدولهاى (9 تا ||(1) كزارش شده است. }
$$

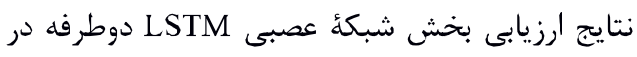

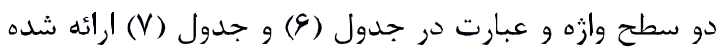

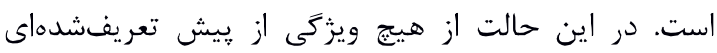
استفاده نشده است. شبكة عصبى بله حجم دادة ائ زيادى نياز
جدولها مشخص است، با استفاده از سامانهُ آمارى به دقت، فراخوانى و درنتيجه F1 بالاترى دست بـ بيدا كرد دهايم. اين مسأله

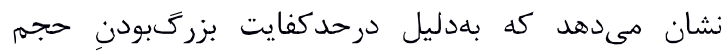

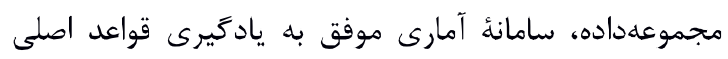

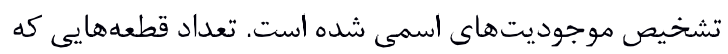
با برجسب زمان در مجموعهداده مشخص شدهانداند، كمتر انداز

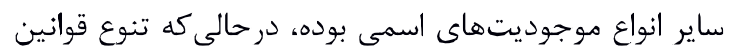

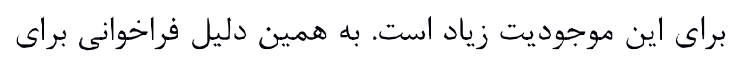

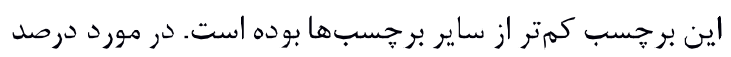

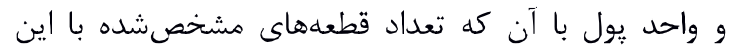

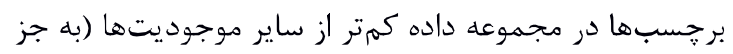

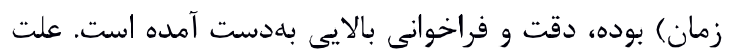

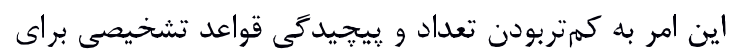
اين دو برجسب برمى كردد.

(جدول -r):نتايج سامانهُ قاعدهمحور - در سطح وازه (Table-2):Rule-based system results - word level

\begin{tabular}{|c|c|c|c|}
\hline F1 & فراخوانى & دقت & نوع موجوديت \\
\hline 0.58 & 0.44 & 0.86 & شخص \\
\hline 0.74 & 0.69 & 0.80 & مكان \\
\hline 0.62 & 0.54 & 0.75 & سازمان \\
\hline 0.66 & 0.52 & 0.92 & زمان \\
\hline 0.48 & 0.33 & 0.86 & تاريخ \\
\hline 0.85 & 0.75 & 0.99 & مبالغ مالى \\
\hline 0.95 & 0.92 & 0.98 & درصد \\
\hline 0.65 & 0.55 & 0.81 & كل \\
\hline
\end{tabular}

(جدول - ؟): نتايج سامانة قاعدهمحور - در سطح عبارت (Table-3):Rule-based system results - phrase level

\begin{tabular}{|c|c|c|c|}
\hline F1 & فراخوانى & دقت & نوع موجوديت \\
\hline 0.58 & 0.44 & 0.86 & شخص \\
\hline 0.74 & 0.69 & 0.80 & مكان \\
\hline 0.63 & 0.54 & 0.75 & سازمان \\
\hline 0.66 & 0.52 & 0.92 & زمان \\
\hline 0.48 & 0.33 & 0.86 & تاريخ \\
\hline 0.85 & 0.75 & 0.99 & مبالغ مالى \\
\hline 0.95 & 0.92 & 0.98 & درصد \\
\hline 0.65 & 0.55 & 0.81 & كل \\
\hline
\end{tabular}

(جدول - (F): نتايج سامانهُ آمارى - سطح وازٔه (Table-4):Statistical system results - word level

\begin{tabular}{|c|c|c|c|}
\hline F1 & فراخوانى & دقت & نوع موجوديت \\
\hline 0.82 & 0.73 & 0.93 & شخص \\
\hline 0.83 & 0.76 & 0.90 & مكان \\
\hline 0.83 & 0.75 & 0.93 & سازمان \\
\hline
\end{tabular}


و 》از" وازكان عمومى هستند كه در بسيارى از رخدادهاى

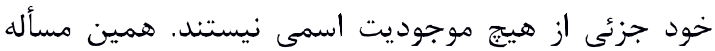

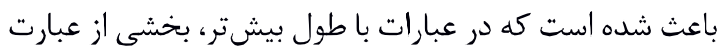

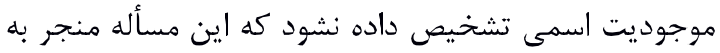

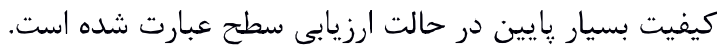

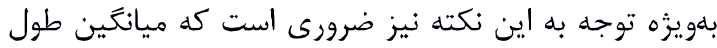

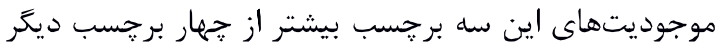

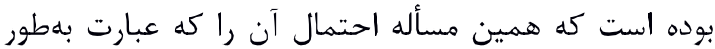
كامل شناسايى شود، كاهش مى دهد.

(جدول -1):نتايج سامانهُ مبتنىىريادكيرى عميق با استفاده از

ويزَّى خروجى CRF- سطح وارَه

(Table-8):Deep-learning based system results with CRF output as a feature - word level

\begin{tabular}{|c|c|c|c|}
\hline كل & فراخوانى & دقت & نوع موجوديت \\
\hline 0.86 & 0.91 & 0.82 & شخص \\
\hline 0.85 & 0.88 & 0.82 & مكان \\
\hline 0.85 & 0.89 & 0.81 & سازمان \\
\hline 0.74 & 0.83 & 0.67 & زمان \\
\hline 0.83 & 0.85 & 0.81 & تاريخ \\
\hline 0.89 & 0.94 & 0.85 & مبالغ مالى \\
\hline 0.92 & 0.93 & 0.90 & درصد \\
\hline 0.85 & 0.89 & 0.81 & كل \\
\hline
\end{tabular}

(جدول -9):نتايج سامانهٔ مبتنىبريادكيرى عميق با استفاده از ويثزى خروجى CRF - سطح عبارت

(Table-9):Deep-learning based system results with CRF output

\begin{tabular}{|c|c|c|c|}
\hline F1 & فراخوانى & دقت & نوع موجوديت \\
\hline 0.77 & 0.79 & 0.74 & شخص \\
\hline 0.83 & 0.81 & 0.84 & مكان \\
\hline 0.71 & 0.70 & 0.71 & سازمان \\
\hline 0.52 & 0.51 & 0.54 & زمان \\
\hline 0.70 & 0.68 & 0.72 & تاريخ \\
\hline 0.58 & 0.59 & 0.57 & مبالغ مالى \\
\hline 0.85 & 0.82 & 0.88 & درصد \\
\hline 0.78 & 0.77 & 0.79 & كل \\
\hline
\end{tabular}

(جدول -+1): نتايج سامانةً تركيبى با استفاده از ويزّى شماره خوشه - سطح واز்

(Table-10):Hybrid system results with cluster number as a feature - word level

\begin{tabular}{|c|c|c|c|}
\hline F1 & فراخوانى & دقت & نوع موجوديت \\
\hline 0.89 & 0.90 & 0.89 & شخص \\
\hline 0.86 & 0.85 & 0.87 & مكان \\
\hline 0.87 & 0.87 & 0.87 & سازمان \\
\hline
\end{tabular}

دارد كه بتواند ساختارها را ياد بخيرد. با توجه به كمبودن حجمم داده با برجسبهاى زمان، تاريخ، درصد و مقادير يولى همانطور كه انتظار مىرفت، كيفيت سامانٔ يادكيرىشده

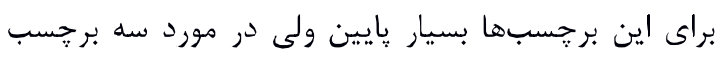
اصلى، كيفيت قابل قبول است. برجين

$$
\text { (جدول - ()):نتايج سامانهُ مبتنى بريادكيرى عميق بدون - سطح وازه }
$$

(Table-6):Deep-learning based system without

\begin{tabular}{|c|c|c|c|}
\hline \\
\hline F1 & فراخوانى & دقت & نوع موجوديت \\
\hline 0.81 & 0.77 & 0.86 & شخص \\
\hline 0.79 & 0.77 & 0.82 & مكان \\
\hline 0.81 & 0.79 & 0.83 & سازمان \\
\hline 0.44 & 0.35 & 0.60 & ز مان \\
\hline 0.70 & 0.67 & 0.72 & تاريخ \\
\hline 0.58 & 0.45 & 0.82 & مبالغ مالى \\
\hline 0.55 & 0.42 & 0.78 & درصد \\
\hline 0.78 & 0.74 & 0.82 & 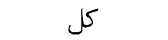 \\
\hline
\end{tabular}
features - word level

(جدول V-:نتايج سامانهُ مبتنىبر يادكيرى عميق بدون

$$
\text { ويز كىى - سطح عبارت }
$$

\begin{tabular}{|c|c|c|c|}
\hline F1 & فراخوانى & دقت & نوع موجوديت \\
\hline 0.69 & 0.67 & 0.71 & شخص \\
\hline 0.73 & 0.76 & 0.70 & مكان \\
\hline 0.59 & 0.63 & 0.55 & سازمان \\
\hline 0.13 & 0.13 & 0.14 & زمان \\
\hline 0.44 & 0.50 & 0.39 & تاريخ \\
\hline 0.03 & 0.03 & 0.03 & مبالغ مالى \\
\hline 0.04 & 0.05 & 0.04 & درصد \\
\hline 0.61 & 0.63 & 0.58 & كل \\
\hline
\end{tabular}

(Table-7):Deep-learning based system without features-phrase level

همانطور كه مشخص است، مدل شبكأ عصبى طبق

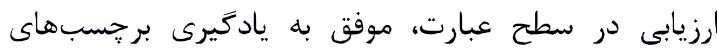
درصد، مقادير يولى و زمان نشده ولى نتايج ارزيابىهاى سطح

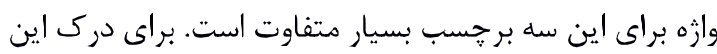

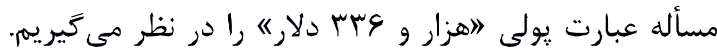
اين عبارت بايد بهطور كامل برجسب مقادير يولى بخيرد؛ ولى يلى مدل LSTM فقط ״وسب دلار" را برجسب مقادير يولى زده و موفق به تشخيص لاهزار وه نشده است. همجنين در مورد

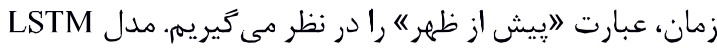

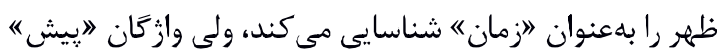




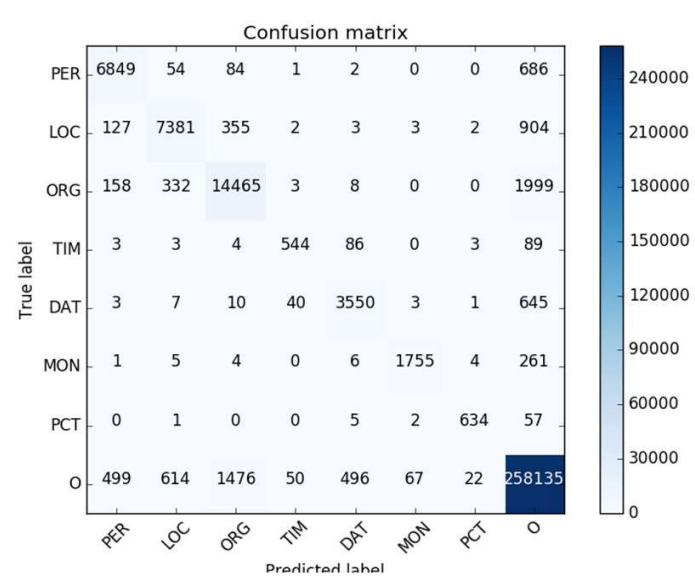

(شكل - f): ماتريس درهمر ريختكَى سامانهُ تشخيص موجوديت اسمى (ستونها بر جسب هاى صحيح و رديفها بر خسب هاى تشخيص

(Figure-4): Confusion matrix of the named entity recognition system (columns are the true labels and rows are the predicted labels)

در شكل (\&) نتايج سامانٔ تركيبى نهايى نشان داده

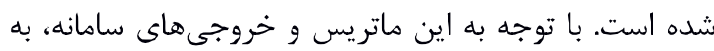

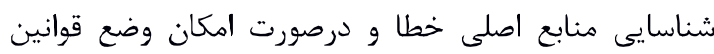
يسيردازشى براى رفع برخى خطاها مى يردازيم.

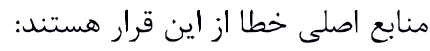

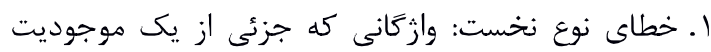

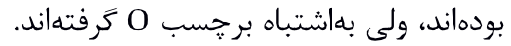

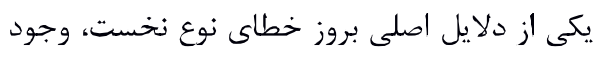

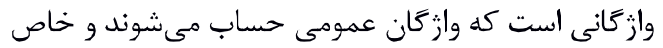

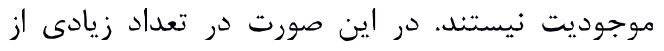

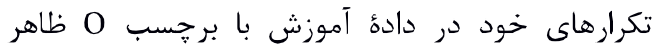
شدهاند و همين امر باعث بروز خطا مىشود. براى مثال

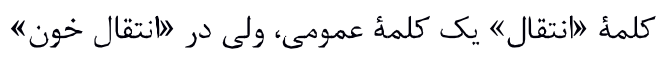
جزئى از يك موجوديت سازمان است. در موارد ديكر، برخى ساختارهاى پيبجيده توسط

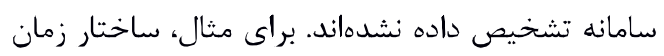

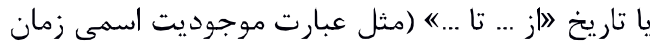

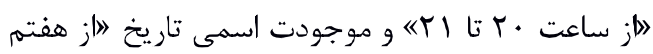

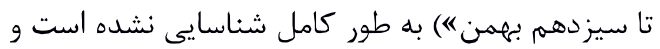

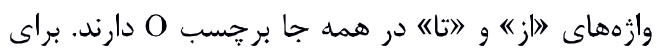

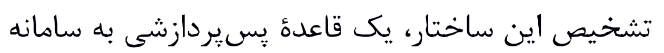

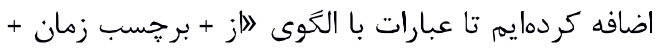

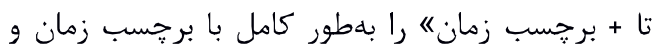

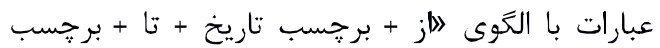
تاريخه را با برجسب تاريخ مشخص كند.

\begin{tabular}{|c|c|c|c|}
\hline 0.76 & 0.66 & 0.91 & زمان \\
\hline 0.87 & 0.80 & 0.89 & تاريخ \\
\hline 0.90 & 0.84 & 0.98 & مبالغ مالى \\
\hline 0.95 & 0.91 & 0.98 & درصد \\
\hline 0.87 & 0.86 & 0.88 & كل \\
\hline
\end{tabular}

(جدول -(I):نتايج سامانة تركيبى با استفاده از ويرُكى شمارؤ

$$
\text { خوشه - سطح عبارت }
$$

(Table-11):Hybrid system results with cluster number as a

\begin{tabular}{|c|c|c|c|}
\hline \multicolumn{4}{|c|}{ feature-phrase level } \\
\hline F1 & فراخوانى & دقت & نوع موجوديت \\
\hline 0.83 & 0.84 & 0.82 & شخص \\
\hline 0.84 & 0.85 & 0.82 & مكان \\
\hline 0.76 & 0.77 & 0.75 & سازمان \\
\hline 0.68 & 0.63 & 0.74 & زمان \\
\hline 0.77 & 0.72 & 0.79 & تاريخ \\
\hline 0.79 & 0.74 & 0.83 & مبالغ مالى \\
\hline 0.91 & 0.90 & 0.92 & درصد \\
\hline 0.80 & 0.81 & 0.80 & كل \\
\hline
\end{tabular}

همانطور كه مشخص است، استفاده از خروجى CRF

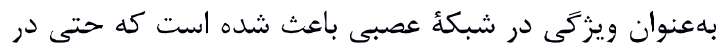

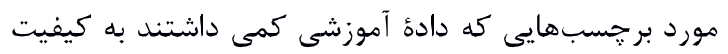

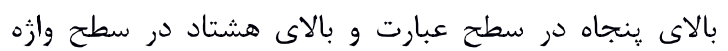

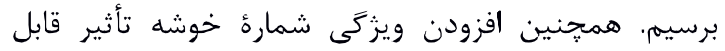

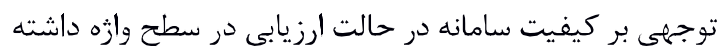

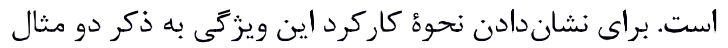

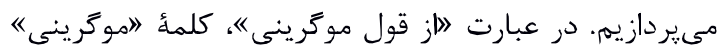

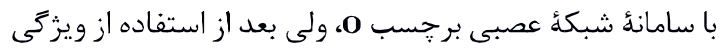

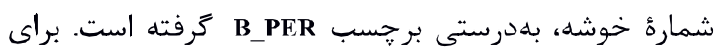

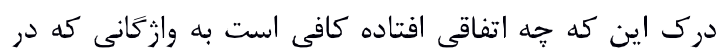

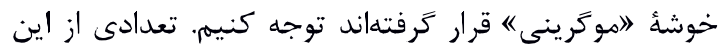

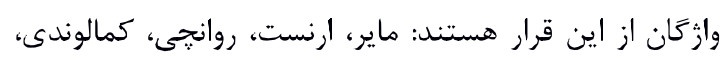

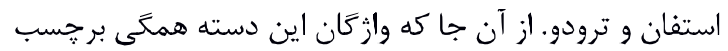

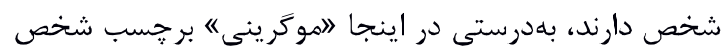

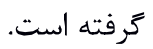

\section{r-ه - تحليل خطا}

براى تحليل نتايج و شناخت منابع خطاى سامانه مى توان بهان به

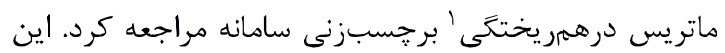

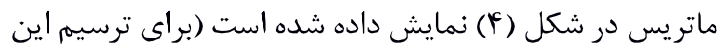

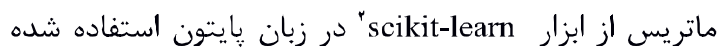

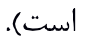

${ }^{1}$ Confusion matrix

${ }^{2} \mathrm{http}$ ://scikit-learn.org/ 
بهنوان يك موجوديت 》تاريخ) تشخيص داده شود؛ ولى الى

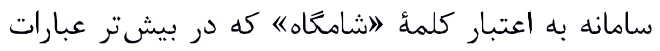

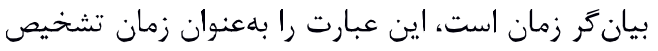

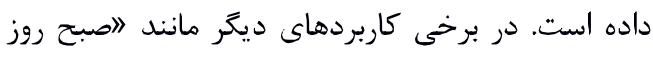

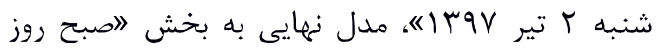

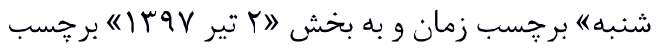

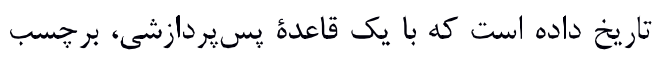

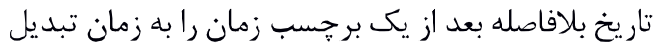
مى كنيم.

ه. خطاى نوع ينجمم و ششه: تشخيص نادرست مكان يا

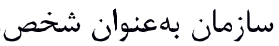

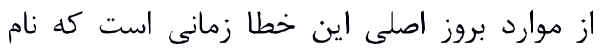

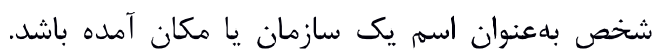
بلهعنوان مثال "امدرسٔ شهيد مطهرى" بايد برحسب

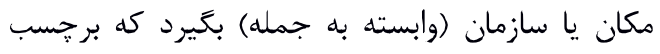
شخص كرفته است يا در عبارت لادفتر نماينده ويثه بان

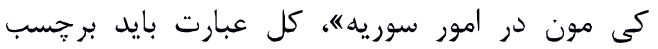

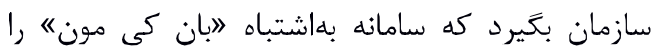

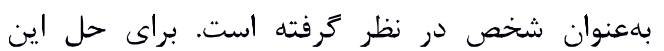
مشكل، با يك قاعدة يس يردازشى، بخشى از يكى عبارت

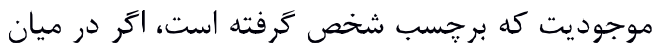

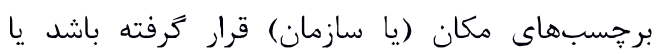
بلافاصله بعد از يك برجسب مكان (يا سازمان) آمدان باشد، تبديل به برجسب مكان (يا سازمان) مىشود.

\section{F- F- مقايسه با ساير سامانهها}

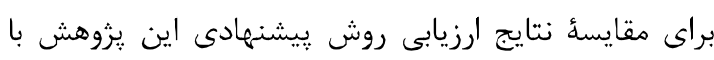

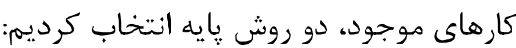

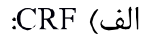

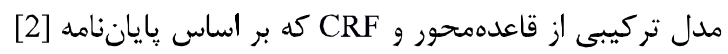

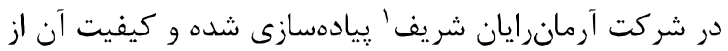

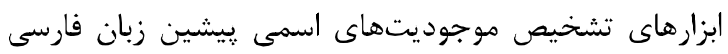

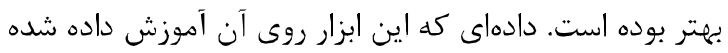

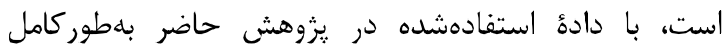
متفاوت بوده است (از نظر نوع، زمان، طول سندها و توزيع

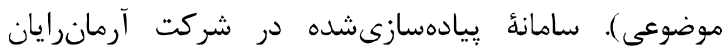

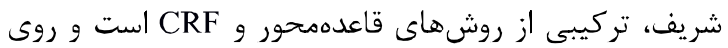
زيرمجموعأ بر جسب خور دهاى از يِيكرة بعى جن خان آموزش داده

شده است.

${ }^{1}$ http://armansoft.ir r. خطاى نوع دوم: وازّكانى كه جزئى از هيج موجوديتى

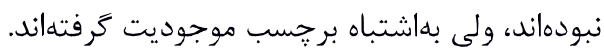

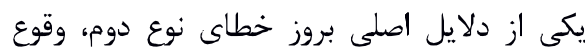

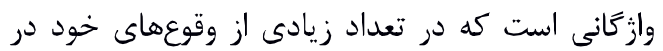

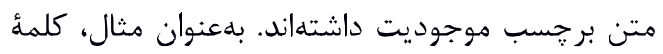

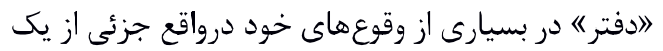
موجوديت سازمان بوده است، ولى در جملهُ لاين برنامه

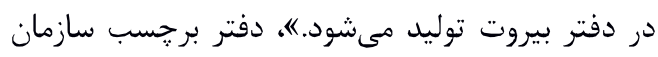

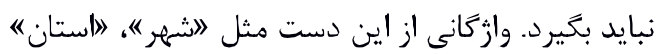

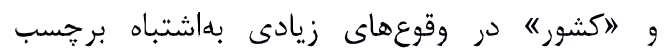

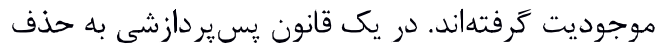

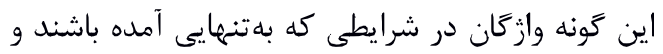

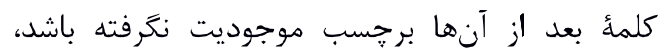

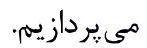
r. خطاى نوع سوم: خطا در تشخيص بين برجسبهاى مكان و سازمان.

خطاى نوع سوم درواقع يك خطاى مفهومى است. بهعنوان مثال، "دانشكاه تهران" در عبارت لاو به دان دانشكاه

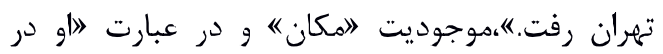

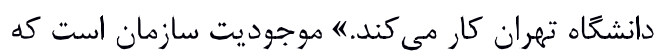

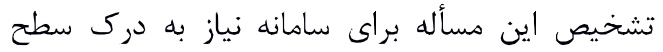

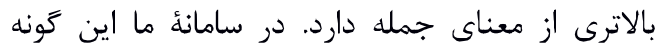
موجوديتها بر جسب الهكان" كرفتهاند.

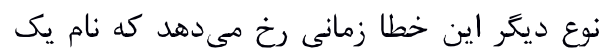

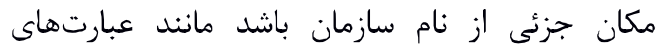

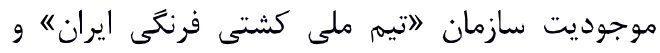

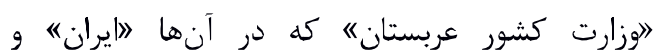

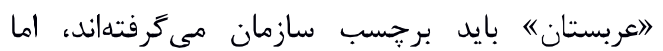
بهاشتباه بلعنوان "مكان" برجسب خوردهاند. براى رفع

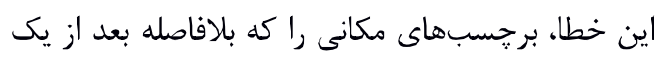

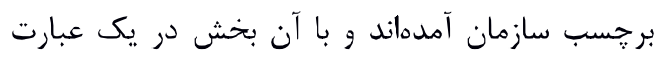

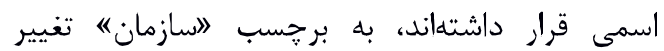
مى دهيم. f. خطاى نوع جهارم: خطا در تشخيص بين بر خسب هاى زمان و تاريخ.

تشخيص موجوديتهاى زمان و تاريخ در بعضى موارد براى كاربر انسانى نيز دشوار است. بهعنوان مثال

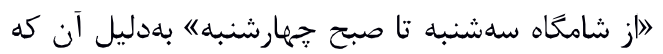

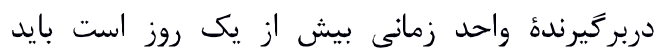




\section{צ- نتيجه كيرى و كارهاى آينده}

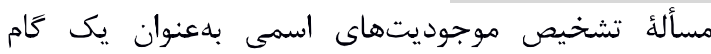

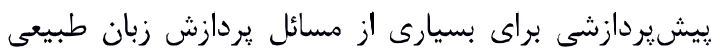

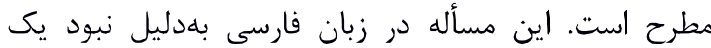

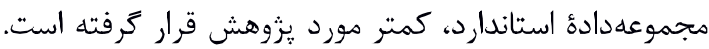

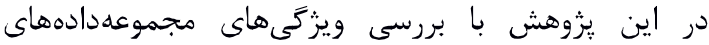

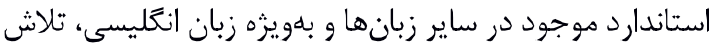

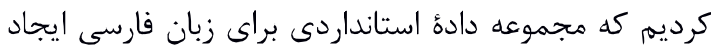
كنيهم. با توجه به اين كه در بسيارى از مجموعهدادههاى

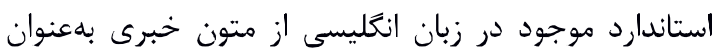

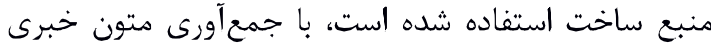

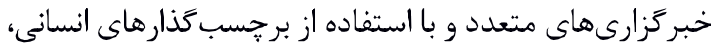

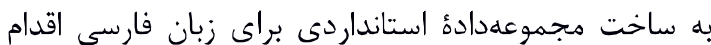
كرديم؟ سيس با مطالعهُ سامانههاى طراحىشده براى تشخيص

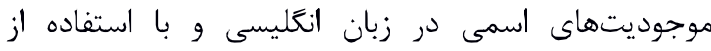
مجموعهدادة تهيهشده به طراحى سامانهاى براى زبان فارسى

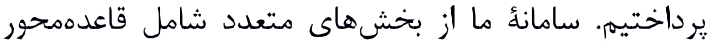

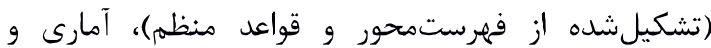

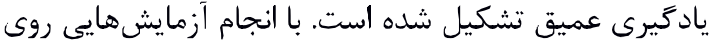

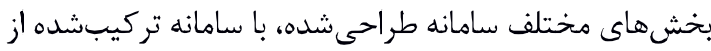

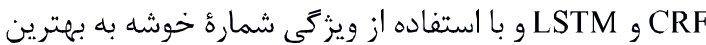

$$
\text { نتيجه بر اساس معيار F1 دست يافتيمه. }
$$

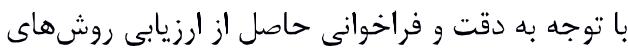

مختلف روى مجموعهداده فراهمشده و با مقايسأ حجم و روش روش

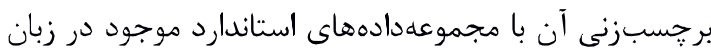

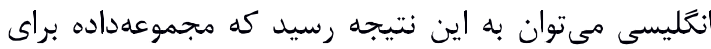

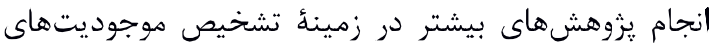

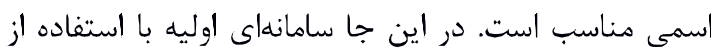
ويزَگىهاى ابتدايى براى تشخيص موجوديتهاى اسمى استى

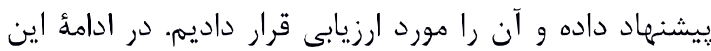

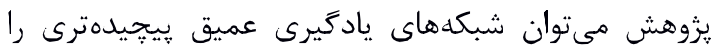

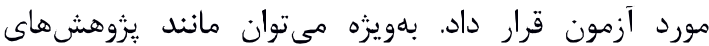

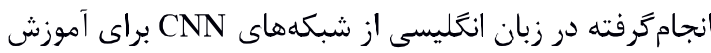

$$
\text { نمايش طيفى نويسهها استفاده كرد. }
$$

\section{تشكر و قدردانى}

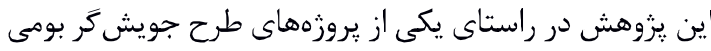

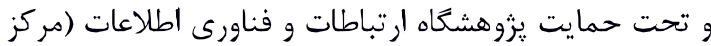

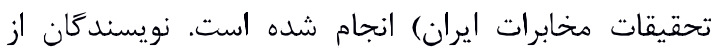
حمايتهاى اين يثوهشكاه قدردانى مى كنند.
ب) تركيب LSTM و LRF

يك روش مستقل از زبان مبتنى بر تركيب LSTM و ل

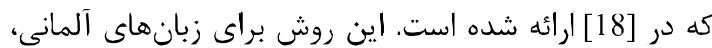
اسيانيايى، انكليسى و هلندى مورد ارزيابى قرار كرفته است كه طبق نتايج اعلامشده، براى دو زبان نخست از بهترين روشي

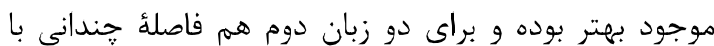
بهترين روش موجود نداشته است، با اين تفاوت كه بر خلاف دماف فران بهترين روشهاى موجود قبلى، نيازى به تعريف و استخراج ويزگى ها ندارد. اين روش در بسيارى دقالات زبانهاى ديخر بهعنوان روش وايه در ارزيابىها مورد استفاده قرار ترفته است.

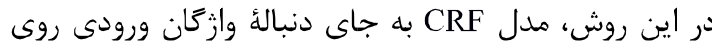

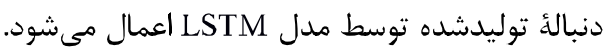
در جدول (r) (I) نتايج ارزيابى سامانهُ پِيشنهادى با دول روش پِيه روى سه برجسب اصلى مقايسه شده است. روش

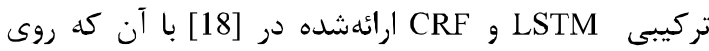
زبانهاى ديگر عملكرد بسيار خوبى نشان داده، روى مجموعهدادة بِيما براى زبان فارسى به كيفيت بسيار ريايينى

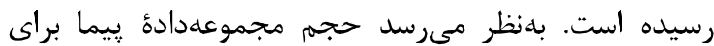

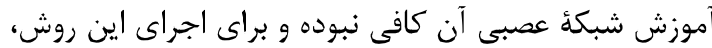
از كد نوشتهشده توسط نويسندكان مقاله استفاده شده است '.

(جدول - Iا): مقايسةً روش بيشنهادى با كارهاى موجود

\begin{tabular}{|c|c|c|c|c|}
\hline \multicolumn{5}{|c|}{ previous works } \\
\hline F1 & فراخوانى & دقت & & روش \\
\hline 0.68 & 0.63 & 0.74 & وازه & $\begin{array}{c}\text { شريف (CRF) شانرايان) } \\
\text { ش2] }\end{array}$ \\
\hline 0.52 & 0.38 & 0.81 & وازه & تركيب \\
\hline 0.46 & 0.44 & 0.48 & سطارت & Cي در [18] CRF \\
\hline 0.87 & 0.87 & 0.87 & سوره & روش | روش \\
\hline 081 & 0.82 & 0.79 & سبارت & رِيشنه|دى \\
\hline
\end{tabular}
(Table-12):Comparison of the proposed method with the

همانطور كه از نتايج مندرج در جدول (r) (I) مشخص

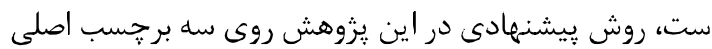

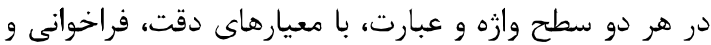
F1 بهتر از روشهاى بايه عمل كرده است.

${ }^{1}$ https://github.com/glample/tagger 
[9] A. Chinchor, "OVERVIEW OF MUC-7 / MET-2 Overviews of English and Multilingual Tasks," in Proceedings of Seventh Message Understanding Conference (MUC-7): Proceedings of a Conference Held in Fairfax, Virginia, April 2, 1997.

[10] J. P. C. Chiu and E. Nichols, "Named Entity Recognition with Bidirectional LSTM-CNNs," in Transactions of the Association for Computational Linguistics, vol. 4 pp. 357 370, 2016.

[11] C. dos Santos and V. Guimar, "Boosting Named Entity Recognition with Neural Character Embeddings," in Fifih Named Entity Recognition Workshop, joint with 53rd ACL and the 7th IJCNLP, 2015, pp. 2533.

[12] J. R. Finkel, T. Grenager, and C. Manning, "Incorporating Non-local Information into Information Extraction Systems by Gibbs Sampling," in Proceedings of the 43rd annual meeting on association for computational linguistics, 2005.

[13] D. Jurafsky and J. H. Martin, Speech and Language Processing: An Introduction to Natural Language Processing, Speech Recognition, and Computational Linguistics, 2nd editio. Prentice-Hall, 2009.

[14] M. K. Khormuji and M. Bazrafkan, "Persian Named Entity Recognition based with Local Filters," International Journal of Computer Applications, vol. 100, no. 4, pp. 1-6, 2014.

[15] M. Konkol, T. Brychcín, and M. Konopík, "Latent semantics in Named Entity Recognition," Expert Systems with Applications, vol. 42, no. 7, pp. 3470-3479, 2015.

[16] G. Kumaran and J. Allan, "Text Classification and Named Entities for New Event Detection," in Proceedings of the $27^{\text {th }}$ annual international ACM SIGIR conference on Research and development in information retrieval, 2004, pp. 297-304.

[17] J. Lafferty and $\Lambda$. Mccallum, "Conditional Random Fields: Probabilistic Models for Segmenting and Labeling Sequence Data Conditional Random Ficlds: Probabilistic Models for Segmenting and," in Proceedings of the eighteenth international conference on machine learning, ICML, 2001, vol. 1, no. June, pp. 282-289.

[18] G. Lample, M. Ballestcros, S. Subramaninan, K. Kawakami, and C. Dyer, "Neural Architectures for Named Entity Recognition," in Proceedings of NAACL-HLT 2016, 2016, no. July.

[19] A. McCallum and W. Li, "Early results for named entity recognition with conditional random fields, feature induction and web-enhanced lexicons," Proceedings of the seventh conference on
7- References

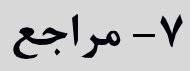

[1] س.ع. اصفهانى، س. راحتى قوجانى و ن. جهانگيرى،

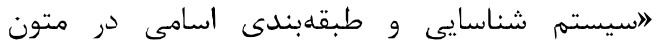

فارسى"، يردازش علايم و دادهها، دوره V شمارئ ل،

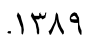

[1] S. A. Esfahani, S. Rahati Ghouchani, and N. Jahangiri, "Persian named entity recognition and classification", Journal of Signal and Data Processing, vol. 7, no. 1, 2010.

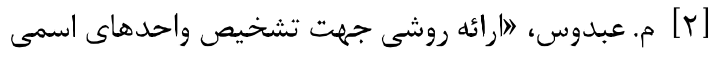

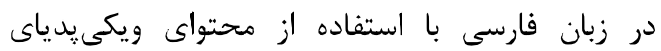

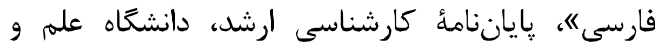

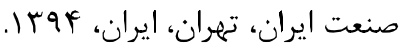

[2]M. Abdous, "Recognizing Persian Named Entities Using Persian Wikipedia Content", M.S Thesis, Iran University of Science and Technology, Tehran, Iran, 2015.

$$
\begin{aligned}
& \text { [r] م. عبدوس و ب. مينايى بيدگلى، "ابهبود شناسايى } \\
& \text { موجوديتهاى نامدار فارسى با استفاده از كسره اضافه巛، }
\end{aligned}
$$

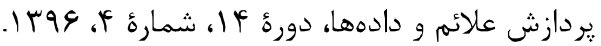

[3] M. Abdous and B. Minaei Bidgoli, "Improving Named Entity Recognition Using Izafe in Farsi", Journal of Signal and Data Processing, vol. 14, no. $4,2017$.

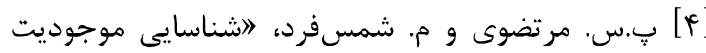

$$
\begin{aligned}
& \text { نامدار در متون فارسى"، يانزدهمين كنفرانس انجمن }
\end{aligned}
$$

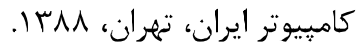

[4] P. S. Mortazavi, M. Shamsfard, "Named Entity Recognition in Persian Texts", in $15^{\text {th }}$ National CSI Computer Conference, Tchran, Iran, 2009.

[5] F. Ahmadi and H. Moradi, "A Hybrid Method for Persian Named Entity Recognition," in $7^{\text {th }}$ Internatonal Conference on Information Knowledge Technology, 2015.

[6] D. M. Bikel, S. Miller, R. M. Schwartz, and R. Weischedel, "Nymble: $\Lambda$ High-Performance Learning Name-Finder", in Proceedings of the fifth conference on Applied natural language processing, pp. 194-201, 1997.

[7] A. Borthwick and J. Sterling, "NYU: Description of the MENE Named Entity System as used in MUC-7," Proceedings of the $7^{\text {th }}$ Message Understanding Conference (MUC-7), 1998.

[8] A. X. Chang and C. D. Manning, "TOKENS REGEX: Defining Cascaded Regular Expressions over Tokens," Stanford University Technical Report, 2004. 


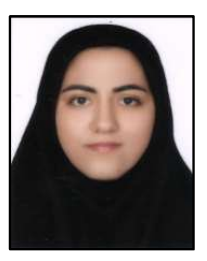

مهساسادات شهشهانى يزوهشكر مقطع دكترا در زمينئ بازيابى و استخراج اطلاعات

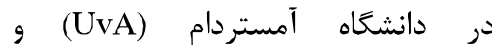
فارغالتحصيل مقطع كارشناسى ارشد

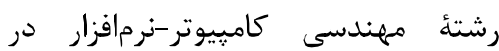
دانشكده مهندسى برق و كامييوتر ٍرديس دانشكدههاى فنى دانشگاه تهران است. اين مقاله حاصل يروهش وى در در زمان كار روى یايان نامئ كارشناسى ارشد است. نشانى رايانامةٔ ايشان عبارت است ازئ

m.shahshahani@uva.nl

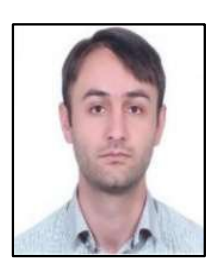

مهدى محسنى دانشجوى دكتراى دانشكده مهندسى برق و كامييوتر دانشعاه تهران در رشته هوش مصنوعى و رباتيك است و به حوزهاى يثزوهشى يردازش زبان

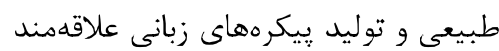
است. يروهش هاى اخير وى در زمينه تشخيص موجوديتهاى اسمى، خلاصهسازى خودكار متون و شبكههاى عصبى- end

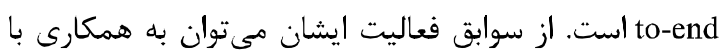
كارگروه خط و زبان فارسى و آزمايشگاه زبانشناسى دانشخاه تهران اشاره كرد. توسعه ابزارهاى تحليل زبانى و توليد منابع

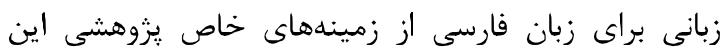

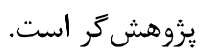
نشانى رايانامئ ايشان عبارت است ازئ mahdi.mohseni@ut.ac.ir

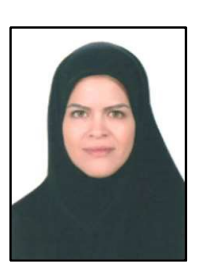
آزاده شاكرى دانشيار دانشـكده مهندسىى

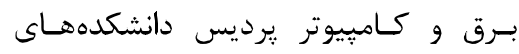

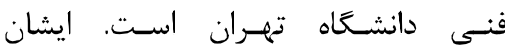

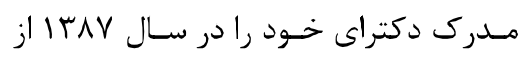

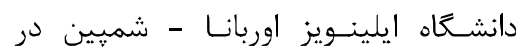

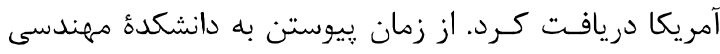

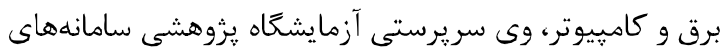

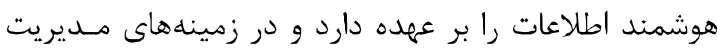

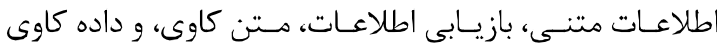

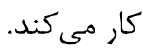
نشانى رايانامئ ايشان عبارت است از: shakery@ut.ac.ir
Natural language learning at HLT-NAACL 2003, vol. 4, 2003,pp. 188-191.

[20] T. Mikolov, G. Corrado, K. Chen, and J. Dean, "Efficient Estimation of Word Representations in Vector Space," in Proceedings of the International Conference on Learning Representations (ICLR 2013), 2013, pp. 1-12.

[21] S. Miller, J. Guinness, and A. Zamanian, "Name Tagging with Word Clusters and Discriminative Training," in Proceedings of HLT-NAACL, 2004.

[22] D. Molla, Me. van Zaanen, and D. Smith, "Named Entity Recogntion for Question Answering," Proceedings of the 2006 Australasian language technology workshop, vol. 4, 2006, pp. 51-58.

[23] D. Nadeau, "A Survey of Named Entity Recognition and Classification," Linguisticae Investigationes, no. 30, p. 3-26., 2007.

[24] M. Pasca, "Acquisition of Categorized Named Entities for Web Search," Thirteenth ACM international conference on Information and knowledge management, 2004, pp. 137-145.

[25] T. Poibcau and L. Kosscim, "Proper Name Extraction from Non-Journalistic Texts," in Proc. Computational Linguistics in the Netherlands, 2001, pp. 144-157.

[26] H. Poostchi and M. Piccardi, "PersoNER: Persian Named-Entity Recognition," in Proceedings of Coling 2016, the $26^{\text {th }}$ International Conference on Computational Linguistics, 2016, pp. 3381-3389.

[27] M. Seok, H. Song, C. Park, J. Kim, and Y. Kim, "Named Entity Recognition using Word Embedding as a Feature 1," International Journal of Software Engineering and Its Applications, vol. 10, no. 2, pp. 93-104, 2016.

[28] S. K. Sien", "Adapting word2vec to Named Entity Recognition," in Proceedings of the $20^{\text {th }}$ Nordic Conference of Computational Linguistics, NODALIDA 2015, 2015, pp. 239-243.

[29] B. M. Sundheim, "Overvicw of Results of the MUC-6 Evaluation," in Proceedings of the $6^{\text {th }}$ conference on Message understanding. Association for Computational Linguistics, 1996, pp. 13-31.

[30] E. F. Tjong, K. Sang, and F. De Meulder, "Language-Independent Named Recognition," in Proc. CoNLL, 2003.

[31] J. Turian, L. Ratinov, Y. Bengio, and J. Turian, "Word Representations: A Simple and General Method for Semi-supervised Learning," Proceedings of the $48^{\text {th }}$ Annual Meeting of the Association for Computational Linguistics, no. July, pp. 384-394, 2010. 


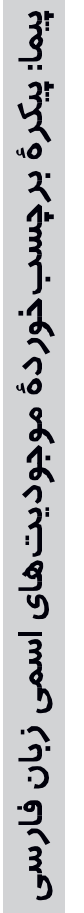

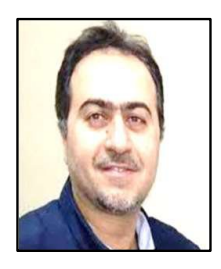

هشام فيلى كارشناسى در كرايش

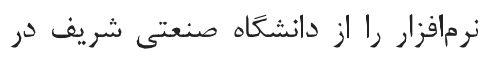

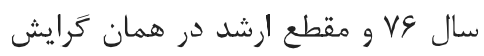

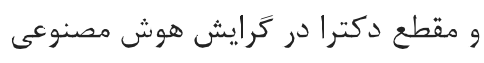

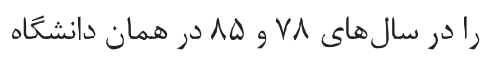

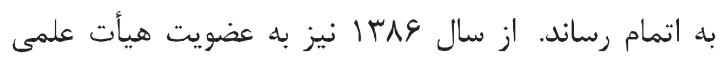

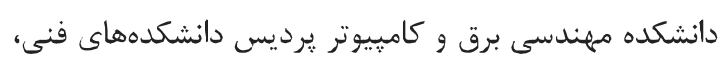

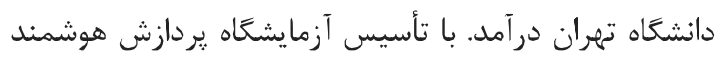

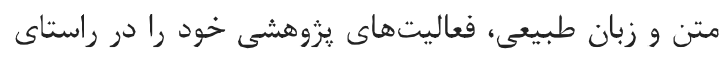

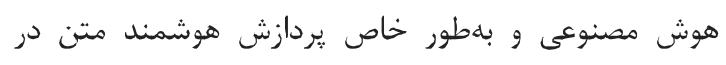
دانشكده مهندسى برق و كامييوتر ادامه داده است.

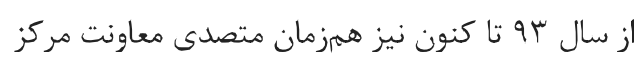
فناورى اطلاعات و فضاى مجازى دانشعاه تهران است. نشانى رايانامة ايشان عبارت است ازئ hfaili@ut.ac.ir

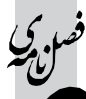

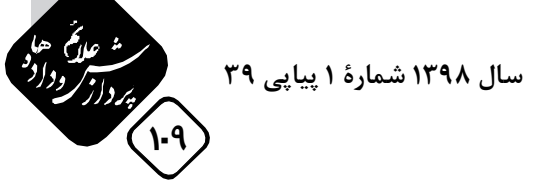


